\title{
Canonical and Non-canonical Reelin Signaling
}

\author{
Hans H. Bock* and Petra May \\ Clinic of Gastroenterology and Hepatology, Heinrich-Heine-University Düsseldorf, Düsseldorf, Germany
}

Reelin is a large secreted glycoprotein that is essential for correct neuronal positioning during neurodevelopment and is important for synaptic plasticity in the mature brain. Moreover, Reelin is expressed in many extraneuronal tissues; yet the roles of peripheral Reelin are largely unknown. In the brain, many of Reelin's functions are mediated by a molecular signaling cascade that involves two lipoprotein receptors, apolipoprotein E receptor-2 (Apoer2) and very low density-lipoprotein receptor (Vldlr), the neuronal phosphoprotein Disabled-1 (Dab1), and members of the Src family of protein tyrosine kinases as crucial elements. This core signaling pathway in turn modulates the activity of adaptor proteins and downstream protein kinase cascades, many of which target the neuronal cytoskeleton. However, additional Reelin-binding receptors have been postulated or described, either as coreceptors that are essential for the activation of the "canonical" Reelin signaling cascade involving Apoer2NIdlr and Dab1, or as receptors that activate alternative or additional signaling pathways. Here we will give an overview of canonical and alternative Reelin signaling pathways, molecular mechanisms involved, and their potential physiological roles in the context of different biological settings.

\section{OPEN ACCESS}

Edited by:

Gabriella D'Arcangelo,

Rutgers, The State Univesity of New Jersey, USA

Reviewed by:

Shin-ichi Hisanaga,

Tokyo Metropolitan University, Japan Brian W. Howell, SUNY Upstate Medical University,

USA

${ }^{*}$ Correspondence: Hans H. Bock hans.bock@med.uni-duesseldorf.de

Received: 02 March 2016 Accepted: 08 June 2016 Published: 30 June 2016

Citation:

Bock HH and May P (2016) Canonical and Non-canonical Reelin Signaling.

Front. Cell. Neurosci. 10:166. doi: 10.3389/fncel.2016.00166
Keywords: neuronal development, synaptic plasticity, Alzheimer disease, amyloid precursor protein, integrin, Eph receptor, coreceptor, protein kinase

\section{PHYSIOLOGICAL ROLES OF REELIN}

Reelin is best known for its role in the developing mammalian cerebral cortex, where it is secreted by Cajal-Retzius cells in the marginal zone and orchestrates the arrangement of postmitotic cortical neurons in an inside-out manner, meaning that younger neurons are located more superficially than the earlier-born neurons. This process is severely disturbed in the spontaneous mouse mutant reeler, where disruption of the gene encoding Reelin leads to an approximate inversion of the cortical layering. Other laminated brain structures are affected as well, resulting in a typical "reeler phenotype", which includes the eponymous reeling gait as a consequence of cerebellar hypoplasia. Characteristic positioning defects of pyramidal and granule neurons in the hippocampus are found as well (reviewed e.g., by Rice and Curran, 2001; Tissir and Goffinet, 2003; D'Arcangelo, 2005). In addition to regulating layer formation in the neocortex and other laminated brain structures, Reelin functions in the developing and adult brain, where Reelin is highly expressed by GABAergic interneurons in the forebrain and by cerebellar granule neurons (Drakew et al., 1998; Pesold et al., 1998; Ramos-Moreno et al., 2006; Wierenga et al., 2010; Pohlkamp et al., 2014). Its functions include the regulation of filopodia formation, dendrite outgrowth, spine formation and synaptogenesis as well as modulation of synaptic plasticity and neurotransmitter release (reviewed by D'Arcangelo, 2005; Herz and Chen, 2006; Levenson et al., 2008; Forster et al., 2010; Levy et al., 2014). 
The study of mutant mice with defects in cortical layering has significantly contributed to our current understanding of corticogenesis (Lambert de Rouvroit and Goffinet, 1998; Hatten and Heintz, 2005; Ogden et al., 2016). However, although the gene affected in reeler mice has been identified more than 20 years ago (D'Arcangelo et al., 1995), our knowledge of how precisely Reelin exerts its diverse functions on neuronal positioning and differentiation on a cellular and molecular level is still imperfect (Caffrey et al., 2014). In accordance with its multiple roles during different developmental stages Reelin targets different cell types, including newborn and differentiated neurons, radial glial cells, astrocytes, and possibly neural stem cells (Forster et al., 2002; Kim et al., 2002; Gong et al., 2007; Lakomá et al., 2011; Brunne et al., 2013; Brunkhorst et al., 2015). Of note, many neuropsychiatric diseases have been associated with dysregulated Reelin expression, including schizophrenia, depression, autism, temporal lobe epilepsy, and neurodegenerative disease (Impagnatiello et al., 1998; Guidotti et al., 2000; Fatemi, 2001; Persico et al., 2001; Haas et al., 2002; Sáez-Valero et al., 2003; Botella-López et al., 2006; Knuesel, 2010; Folsom and Fatemi, 2013). Reelinresponsive cells outside the central nervous system remain mostly elusive, although significant amounts of Reelin are detected in plasma and various non-neuronal tissues (Ikeda and Terashima, 1997; Smalheiser et al., 2000; Kobold et al., 2002; Lugli et al., 2003; Botella-Lopez et al., 2008), and functional effects of Reelin on blood cells such as platelets (Tseng et al., 2014), endothelial cells (Ding et al., 2016), or pancreatic cancer cell lines (Sato et al., 2006) have been described.

\section{TOWARDS A MOLECULAR UNDERSTANDING OF THE REELER PHENOTYPE: THE CORE REELIN SIGNALING CASCADE}

The discovery of spontaneous or genetically engineered mutant mouse lines that copy the reeler phenotype (Table 1) in combination with biochemical apporaches for identifying protein interactions proved instrumental in the discovery of a Reelin-dependent core signaling pathway (Figure 1) that underlies many of the established biological functions of Reelin in the developing and mature brain.

These include mice lacking the intracellular phosphoprotein Disabled-1 (Dab1) and compound mutant mice that lack both very low density lipoprotein receptor (Vldlr) and apolipoprotein E receptor 2 (Apoer2), which are two close relatives of the low density lipoprotein (LDL) receptor, the prototype of an endocytic receptor and founding member of the LDL receptor gene family (reviewed by Herz, 2001; Herz and Bock, 2002). This discovery is a prime example for the power of mouse genetics and came as a surprise, since so far lipoprotein receptors had not been connected with the transduction of extracellular signals via classical signaling cascades (Howell and Herz, 2001; May et al., 2003a).
TABLE 1 | Mouse mutants with a reeler-like phenotype.

\begin{tabular}{|c|c|c|c|}
\hline Mouse & Gene & & Reference \\
\hline $\begin{array}{l}\text { reeler-Jackson } \\
\text { reeler-Orleans }\end{array}$ & $\begin{array}{l}\text { Reln } \\
\text { Reln }\end{array}$ & $\begin{array}{l}\text { spont. } \\
\text { spont. }\end{array}$ & $\begin{array}{l}\text { Falconer (1951) } \\
\text { de Bergeyck et al. (1997) } \\
\text { Hirotsune et al. (1995) }\end{array}$ \\
\hline reeler-sf transgene & Reln & fort. & $\begin{array}{l}\text { Miao et al. (1994) } \\
\text { D'Arcangelo et al. (1995) }\end{array}$ \\
\hline Meox2-Cre-Reln lox/lox & Reln & targ. & Lane-Donovan et al. (2015) \\
\hline $\begin{array}{l}\text { Apoer2 } 2^{-1-} ; \text { Vldllr } \\
\text { yotari }\end{array}$ & $\begin{array}{l}\text { Lrp8, Vldlr } \\
\text { Dab1 }\end{array}$ & $\begin{array}{l}\text { targ. } \\
\text { fort. }\end{array}$ & $\begin{array}{l}\text { Trommsdorff et al. (1999) } \\
\text { Sheldon et al. (1997) } \\
\text { Yoneshima et al. (1997) }\end{array}$ \\
\hline scrambler & Dab1 & spont. & $\begin{array}{l}\text { Sweet et al. (1996), } \\
\text { Sheldon et al. (1997) }\end{array}$ \\
\hline Dab1-/- & Dab1 & targ. & Howell et al. (1997) \\
\hline $\mathrm{Dab} 1^{5 \mathrm{~F} / 5 \mathrm{~F}}$ & Dab1 & targ. & Howell et al. (2000) \\
\hline $\mathrm{Src}^{-1-} ; \mathrm{Fyn}^{-1-}$ & Src, Fyn & targ. & Kuo et al. (2005) \\
\hline $\begin{array}{l}\text { Nestin-Cre-Crklox/lox; } \\
\text { CrkL lox/lox }\end{array}$ & Crk, CrkL & targ. & Park and Curran (2008) \\
\hline
\end{tabular}

The analysis of brain phenotypes of mutant mice proved essential for the elucidation of a core Reelin signaling pathway with $L D L$ receptor gene family members as canonical receptors. Mice lacking either Reelin (ligand, green), Apoer2 and VIdIr (receptor, orange), Dab1 (intracellular phosphoprotein, kinase switch and adapter protein, red), Fyn and Src (Src family nonreceptor tyrosine kinase, blue) or Crk and CrkL (adapter proteins, purple) display a reeler-like phenotype, which is defined by characteristic neuroanatomical defects of laminated brain structures. Inactivation of additional Reelin effector genes causes more circumscribed defects, depending on the degree or spatiotemporal pattern of inactivation, or indicating more specialized functions. Spontaneous (spont.) or targeted (targ.) gene deletions are indicated; reeler-transgene and yotari mice were the result of the fortuitous (fort.) insertion of a mutated Fos transgene (sf) into the Reln locus or a random mutation of the Dab1 gene during the generation of IP3R deficient mice, respectively.

By demonstrating that Reelin directly binds to the extracellular domains of Apoer2 and Vldlr (D'Arcangelo et al., 1999; Hiesberger et al., 1999), which interact with the protein interaction/phosphotyrosine-binding (PTB) domain of Dab1 via the tetra-amino-acid NPXY endocytosis motif within their intracellular tails (Howell et al., 1999b; Gotthardt et al., 2000), a linear signaling pathway was established that leads to the tyrosine phosphorylation of Dab1 (Howell et al., 1999a; Rice and Curran, 1999; Figure 2A). Alternative models that were compatible with the observed mouse phenotypes (Cooper and Howell, 1999), where the lipoprotein receptors were placed downstream, or in parallel, to a Reelin-Dab1 dependent pathway, could thus be ruled out. Although either Apoer2 or Vldlr alone is sufficient for inducing Reelinmediated Dab1 tyrosine phosphorylation in primary cultures of cortical neurons (Beffert et al., 2002; Bock and Herz, 2003), the neurodevelopmental phenotypes of the single knockout mice hint at divergent functions of both lipoprotein receptors in the transmission of the Reelin signal. These differences might be attributable to a different regional, cellular and subcellular distribution of both receptors, temporal differences in receptor expression and biochemical properties, including ligand affinities, intra- and extracelullar interaction partners, receptor turnover or processing by proteases (see below). 


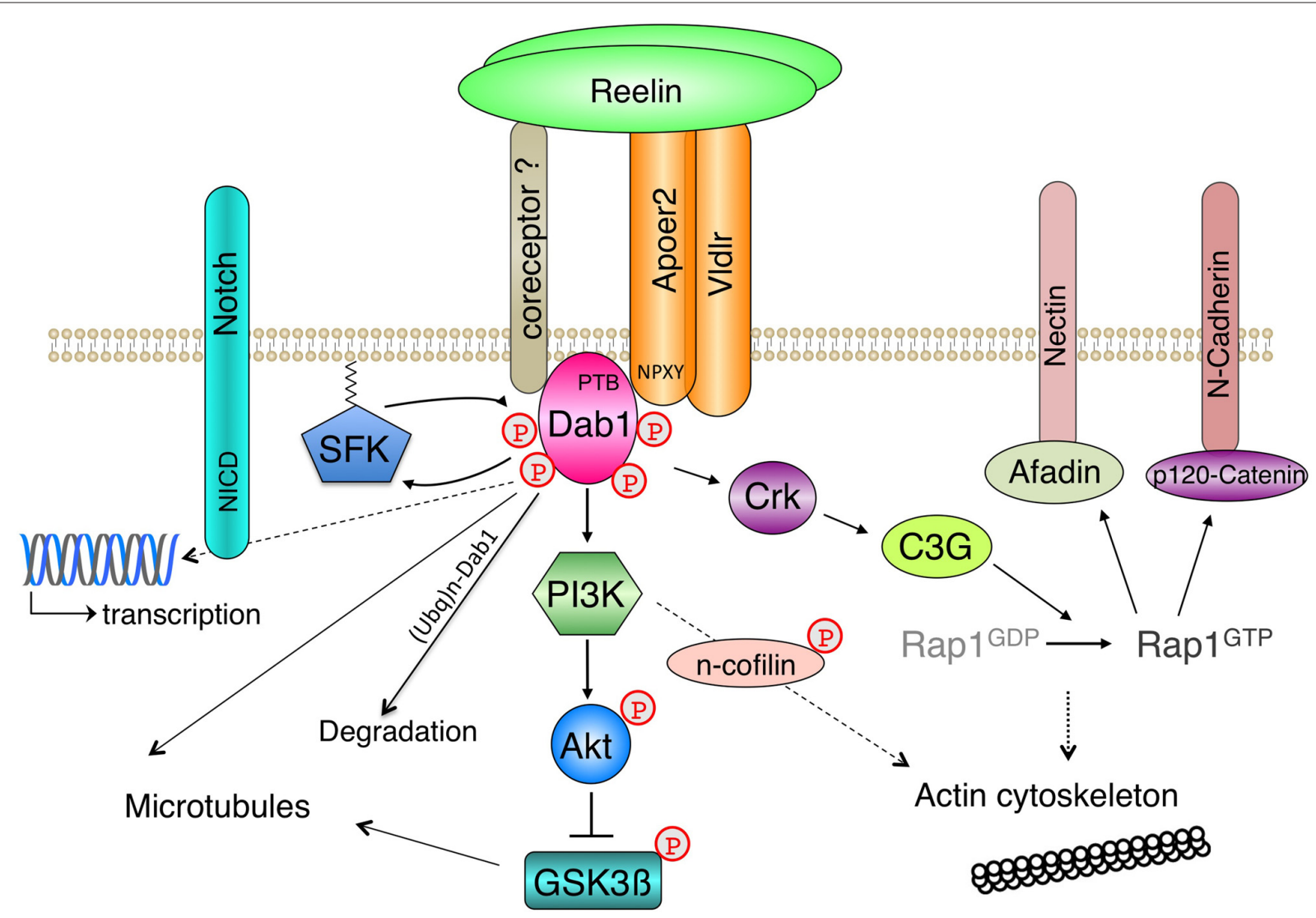

FIGURE 1 | Core Reelin signaling pathway. A simplified scheme of Reelin-induced signaling events in neurons is shown. Based on a combination of phenotypic analysis of mouse mutants and biochemical studies a core Reelin signaling pathway was identified, where lipoprotein receptors interact with the phosphotyrosine-binding (PTB) domain of Disabled-1 (Dab1) via the NPXY motif in their intracellular domains. Oligomerized Reelin induces clustering of the receptor-Dab1 complexes, which induces tyrosine phosphorylation of Dab1 by Src family kinases (SFK) at different sites. This leads to site-specific modification of downstream signaling effectors, which is discussed in more detail in the text. The reciprocal activation of Src kinases (SFK) and Dab1, which underlies the prolonged increase of Dab1 phosphorylation after Reelin stimulation, is negatively regulated by p-Dab1 ubiquitinylation and degradation. It is unclear to what degree Apoer2 and VIdlr are coclustered by Reelin. Inhibition of the serine/threonine kinase Gsk3ß via Akt was the first described lipoprotein receptor-and Dab1-dependent linear Reelin signaling cascade in neurons, which targets the cytoskeleton. Reelin binds to additional transmembrane proteins (coreceptors) that also interact with Dab1, which are not essential for the tyrosine phosphorylation of Dab1 but might be involved in receptor crosstalk and/or activation of additional downstream effectors. Long-lasting changes in responsive cells are induced by transcriptional regulation, which involves the gamma-secretase mediated release of receptor intracellular domains. The regulation of transmembrane proteins ( $\mathrm{N}$-Cadherin, Nectin) downstream of a Reelin-Dab1-Crk/CrkL-Rap1-dependent signaling cascade has been shown to be essential for Reelin's role during neurodevelopment.

\section{Tyrosine Phosphorylation of Dab1: The Coreceptor Controversy}

Subsequent studies focused on the identification of the tyrosine kinase(s) that are required for the phosphorylation of Dab1 at four tyrosyl residues close to its PTB domain, which is essential for Dab1's function during brain development. This was demonstrated by the generation of mice that express a Dab1 protein with phenylalanine substitutions at Tyr185, 198/200, 220 and 232 (Dab1 ${ }^{5 F / 5 F}$; Howell et al., 2000). Since, unlike receptor tyrosine kinases, the lipoprotein receptors do not contain a cytoplasmic kinase domain, it was speculated from the beginning that a Reelin coreceptor with associated tyrosine kinase activity (either intrinsic or by forming a complex with a nonreceptor tyrosine kinase) might be required (e.g., Cooper and Howell, 1999, Figure 2C). Biochemical studies identified members of the Src family of nonreceptor tyrosine kinases as physiological Dab1 kinases (Arnaud et al., 2003b; Bock and Herz, 2003), which was confirmed genetically by the demonstration of a reeler-like phenotype in double-knockout mice lacking both Src and Fyn (Kuo et al., 2005). Members of the gene family of cadherin-related neuronal receptors (CNR), which are expressed in the cortical plate and bind to Fyn with their cytoplasmic domains, were reported to interact with the aminoterminal region of Reelin (Senzaki et al., 1999) and therefore considered as likely coreceptor candidates that would bring Fyn into a Reelin-lipoprotein receptor-Dab1 complex (Figure 2C). However, this interaction was not confirmed using an in vitro pulldown assay with recombinantly expressed CNR extracellular domain and secreted Reelin (Jossin et al., 2004), and an in vivo evaluation of CNR family members as obligatory coreceptors by loss-of-function studies has not been provided. In another study it was suggested that ephrin B receptors, 


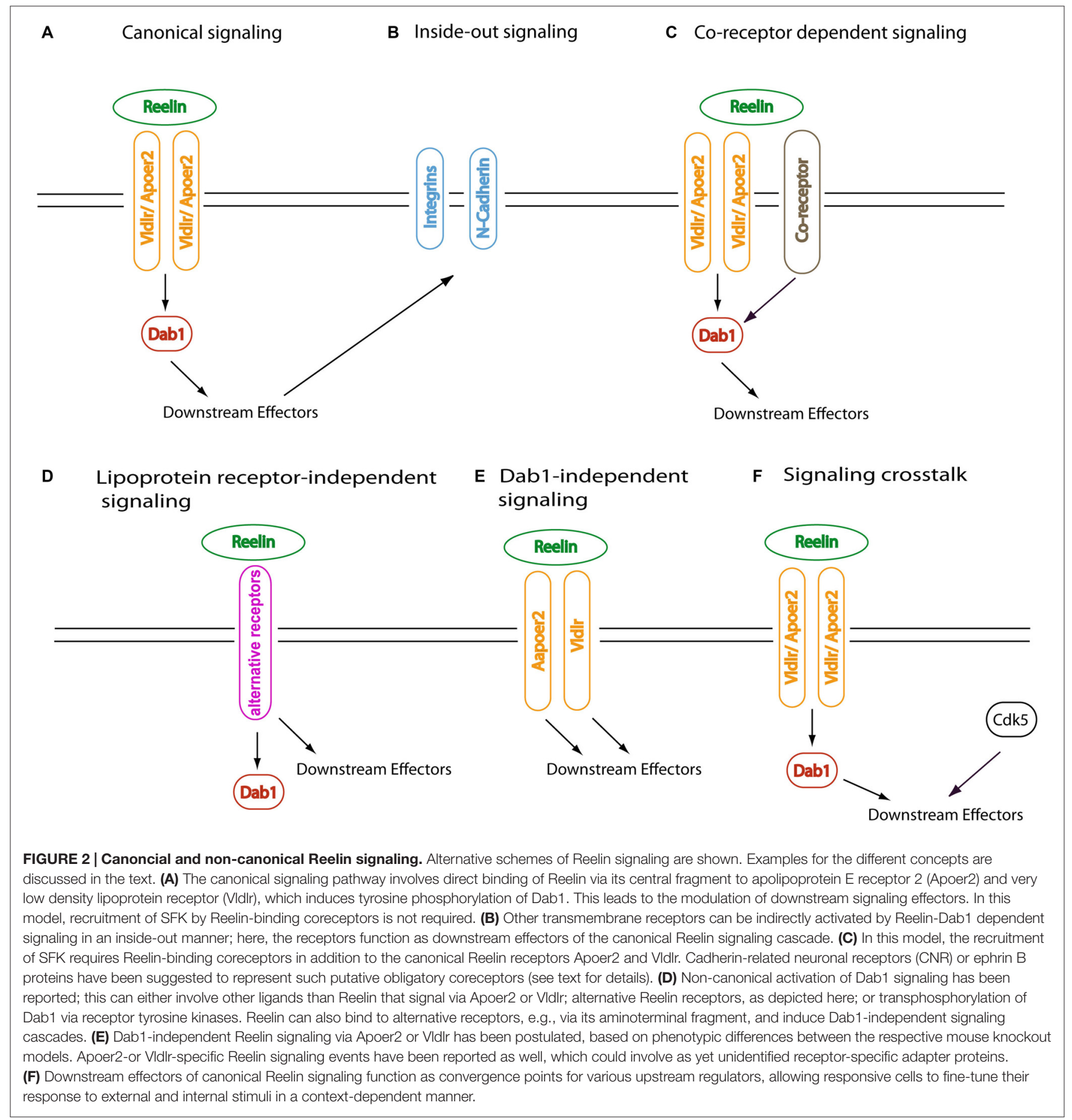

transmembrane proteins that interact with Eph receptors to initiate bidirectional signaling (Pasquale, 2008), act as essential Reelin coreceptors, which would be required for the recruitment and activation of Src family kinases (SFK) into the lipoprotein receptor-Dab1 complex at the cell membrane (Sentürk et al., 2011; and Erratum in Nature 2011, 478:274). This model was based on both biochemical and genetic experiments, including precipitation of the reeler phenotype in mice carrying only one reeler allele on an ephrin B3 knockout background, and the analysis of ephrin B triple knockout mice, which were described to display a reeler-like phenotype in the neocortex, hippocampus and cerebellum (Sentürk et al., 2011). In addition, a rescue of the cortical lamination defects in organotypic cortical slice cultures from reeler embryos after 2 days of treatment with ephrin B ligand was reported (Sentürk et al., 2011). However, whereas binding of recombinant Reelin to the purified extracellular domain of ephrin B3 was confirmed, the clustered recombinant Ephb3 extracellular domain did 
not induce Dab1 tyrosine phosphorylation, as tested by Dab1 immunoprecipitation followed by immunoblotting with the phosphotyrosine antibody 4G10 (Bouché et al., 2013). To verify ephrin B transmembrane proteins as essential components of the canonical Reelin signaling cascade, the independent reproduction of a reeler-like phenotype in compound mutant mice would be necessary. In summary, the existence of an additional coreceptor that is required for the tyrosine phosphorylation of Dab1, which is the essential step for the intracellular propagation of the Reelin signal in the canonical pathway, has not been convincingly demonstrated to date.

On the other hand, a considerable body of evidence supports the concept that di- or oligomerization of the lipoprotein receptors Apoer2 and Vldlr, which bind to the central fragment of Reelin (Jossin et al., 2004; Yasui et al., 2010), is sufficient to explain the tyrosine phosphorylation of Dab1 induced by Reelin and its physiological consequences. Reelin is secreted as a disulfide-linked oligomer and forms higher-order multimers (Utsunomiya-Tate et al., 2000; Kubo et al., 2002; Jossin et al., 2004; Yasui et al., 2010, 2011; Manoharan et al., 2015). A conformation-dependent epitope close to the aminoterminal region of Reelin, which is recognized by the function-blocking CR50 monoclonal antibody, is required for homodimerization, and clustered (but not monomeric) receptor-associated protein (RAP), an extracellular lipoprotein receptor ligand, or antibodies directed against the extracellular domains of Apoer2 or Vldlr were able to induce Dab1 tyrosine phosphorylation (Strasser et al., 2004). This was complemented by demonstrating that chemically inducible homodimerization of a Dab 1-FKBP12 fusion protein in heterologous cells was sufficient to induce receptor-independent tyrosine phosphorylation in a SFK-dependent manner (Strasser et al., 2004). Altogether, these studies support the hypothesis that Reelin can induce Apoer2/Vldlr-dependent signaling by clustering Dab1 on the cytoplasmic leaflet of the plasma membrane, bringing it into close proximity with SFK, without the need for an additional coreceptor.

\section{Signaling Events Downstream of Dab1}

Here, we will focus on molecular events that regulate Dab1 activation and turnover (and thereby the duration of the Reelin signal) by modulating Src kinase activity, and the Reelindependent formation of phospho-Dab1-mediated scaffolding complexes that activate downstream signaling cascades. The Dab1-dependent inside-out activation of other transmembrane receptors involving Rap1 will be discussed in the next chapter.

\section{Feedback Regulation of Reelin Signaling by Dab1 Degradation}

Previous studies demonstrated that tyrosine-phosphorylated Dab1 potentiates SFK activation by a positive feedback mechanism (Bock and Herz, 2003), which is limited by the Cullin 5 and SOCS/Rbx2-dependent ubiquitinylation and proteasomal degradation of tyrosine-phosphorylated, activated Dab1 (Arnaud et al., 2003a; Bock et al., 2004; Feng et al., 2007; Simó et al., 2010; Simó and Cooper, 2013; Lawrenson et al., 2015). This places the SFK both upstream and downstream of Dab1. Of note, expression of a mutant Dab1 protein that was phosphorylatable but partly resistant to Cullin-induced degradation in electroporated embryonic brains caused overmigration of cortical neurons, indicating that Dab1 degradation is an essential part of the Reelindependent regulation of neuronal positioning in the developing cortical plate (Simó et al., 2010). Accordingly, positioning defects in mice with a conditional deletion of Rbx2 in neuronal progenitors were partially rescued by reducing Dab1 levels through Dab1 heterozygosity, which suggests that accumulation of (phosphorylated) Dab1 by the inability to turn the Reelin signal off causes migration defects (Simó and Cooper, 2013). Conditional deletion of the GTPase-activating protein (GAP) tuberin (Tsc2), which is mutated in the genetic disorder tuberous sclerosis, leads to neuronal migration defects in the cortex, hippocampus and cerebellum that are reminiscent of but not identical with the reeler phenotype (Moon et al., 2015). The defects were traced to a defect in Reelin-Dab1dependent signaling, which is caused by increased activation of mTor kinase and subsequent aberrant expression of the ubiquitin ligase Cullin 5, decreased levels of activated Fyn and phosphorylated Dab1, and increased total Dab1 levels, a biochemical hallmark of defective Reelin-Dab1 signaling (Rice et al., 1998). Interestingly, Reelin also activates mTor in an Akt-dependent manner to regulate growth and branching of hippocampal neurons (Jossin and Goffinet, 2007). An additional link between Reelin and mTor signaling is suggested by the reciprocal regulation of Golgi morphology by Reelin-Dab1 and Lkb1 signaling (Matsuki et al., 2010), which also inhibits mTor by activating Tsc2.

\section{The Relevance of Different Tyrosine Phosphorylation Sites of Dab1}

Molecular targets downstream of Dab1 depend on the phosphorylated tyrosine residues. By generating mice with tyrosine to phenylalanine exchanges either at amino acids 185 and 198/200 (ab) or at positions 220 and 232 (cd) of Dab1 (Feng and Cooper, 2009) provided in vivo evidence for a dual role of Dab1 both as a SFK activator and a phosphorylationdependent scaffold for the assembly of downstream signaling complexes. The $D a b 1^{\mathrm{ab}}$ and $D a b 1^{\mathrm{cd}}$ homozygous mice displayed abnormal development of the neocortex and hippocampus, with intermediate cerebellar phenotypes when compared with mice lacking all five tyrosine phosphorylation sites (Howell et al., 2000). Mice hemizygous for each of the mutant alleles $\left(D a b 1^{\mathrm{ab} / \mathrm{cd}}\right)$ showed no morphological brain abnormalities, which indicates that the two sites have individual functions that are required together to support normal brain development. Specifically, the ab site is required for SFK activation (Arnaud et al., 2003b; Bock and Herz, 2003), Dab1 phosphorylation and degradation, and PI3 kinase activation (Beffert et al., 2002; Bock et al., 2003), whereas phosphorylation of the cd site is important for the assembly of Crk/CrkL signaling complexes as well as for the interaction with other adapter proteins such as Nck2 or Crk family members (Pramatarova et al., 2003; Chen et al., 2004; Huang et al., 2004). Recently, Lawrenson et al. (2015) described a role for the tyrosyl residue at position 300 of Dab1, in concert 
with Y200, for the interaction with SOCS6 and 7, two SH2containg proteins that are components of the ubiqutin-E3 ligase complex which is responsible for the proteasomal degradation of phosphorylated Dab1. Mice lacking SOCS6 and SOCS7 display a cortical layer inversion phenotype reminiscent of reeler mice and express increased levels of phosphorylated Dab1; however, Reelin-dependent phosphorylation at the Y300 site has not been directly demonstrated yet.

A requirement for PI3 kinase and Akt for normal cortical plate development was demonstrated in an organotypic brain slice culture assay by using chemical inhibitors (Bock et al., 2003; Jossin and Goffinet, 2007), although dominant-negative (DN) kinase-inactive Aktl expressed under control of a neuronspecific Dcx promoter and electroporated into embryonic mouse brain at E12.5 did not affect glia-independent somal translocation (Franco et al., 2011). As would be expected, further branching of the signaling cascade leads to the activation of effectors like cofilin (Chai et al., 2009, 2016), which will not be discussed in detail here. Interestingly, the somatic activation of another Akt isoform, Akt3, in focal malformations of cortical development is responsible for noncell autonomous cortical migration defects, which lead to drugresistant epilepsy (Baek et al., 2015). Here, the migration defect is caused by Foxg1-mediated ectopic misexpression of Reelin.

The scaffolding function of Dab1 phosphorylated at the cd sites is essential for normal development. This is underscored by the reeler-like phenotype of mice where the adapter proteins Crk and CrkL were simultaneously deleted in the developing nervous system (Park and Curran, 2008). Since they are located downstream of phosphorylated Dab1 in the Reelin signaling cascade, Dab1 protein levels were not increased in the brains of Crk/CrkL double-mutant mice. Reelin-induced phosphorylation not only of the Crk/CrkL-binding guanine nucleotide exchange factor (GEF) C3G, which activates the small GTPase Rap1 (Gotoh et al., 1995), but also of the serine/threonine kinase Akt/protein kinase B (PKB) at position 473 was inhibited in Crk/CrkL-deficient neurons (Park and Curran, 2008). The latter might be a consequence of a loss of the direct interaction of the PI3K regulatory subunit p85 with Crk, which was shown in $\mathrm{T}$ lymphocytes (Gelkop et al., 2001).

\section{Regulation by Constrained Localization and Differential Splicing of Dab1}

In cultured neurons, Dab1 and Apoer2 are enriched in the distal dendrite of neurons (Howell et al., 1999b; Leemhuis et al., 2010), where Reelin stimulation leads to a localized increase of overall tyrosine phosphorylation (Beffert et al., 2002). The localized action of Reelin signaling is important for the activitydependent enrichment of HCN1 and GIRK1 ion channels in the distal dendritic tuft of hippocampal CA1 and neocortical layer $\mathrm{V}$ pyramidal neurons, thereby modulating the molecular specification of the distal dendritic compartment (Kupferman et al., 2014).

Another level of regulation may be provided by differential splicing of the Dab1 gene (Bar et al., 2003; Gao and Godbout, 2013). In mice lacking the RNA-binding protein Nova2 a migration defect of late-born cortical neurons was observed. This phenotype was dependent on the overrepresentation of an alternatively spliced form of Dab1 during a critical time window between E14.5 and E16.5, which is normally suppressed by the splicing factor Nova2 (Yano et al., 2010).

\section{Dab1-Dependent Inside-Out Activation of Cell Surface Receptors by Reelin}

Several studies addressed the role of Rap1, which is activated through the Reelin-Dab1-Crk-C3G pathway (Ballif et al., 2004), during neocortical development. C3G hypomorphic mice display cortical migration defects resulting in a failure of preplate splitting similar to reeler mice, and defects in radial glial processes (Voss et al., 2008). Inactivation of neuronal Rap1 by in utero electroporation of the gene encoding Rap1Gap, a GAP that specifically inactivates Rap1 by stimulating its GTP hydrolysis, or Rapla shRNA, disrupted glia-independent somal translocation of migrating neurons. This effect was dependent on neuronal Cadherin-2 (NCAD, Cdh2), a transmembrane protein that mediates cell-cell adhesion. Cdh2 overexpression rescued the migration defect caused by Rap1GAP overexpression, placing it downstream of Rap1 as an example of inside-out activation of a cell surface receptor. However, the Dab1 null phenotype was not rescued by Cdh2 overexpression, which underscores the pleiotropic nature of Reelin-Dab1 signaling affecting different developmental stages, cellular and molecular levels of action (Franco et al., 2011). This is exemplified by two other important studies using in utero electroporation of embryonic brains, which confirmed the importance of Reelindependent Rap1 activation for neuronal migration in the developing neocortex (Jossin and Cooper, 2011; Sekine et al., 2012). Sekine et al. (2012) found that Cdh2 overexpression did not fully rescue the Rap1 suppression phenotype and provided evidence for an additional role of Dab1-Crk-C3G-Rap1 dependent inside-out activation of integrin $\beta 1-\alpha 5$ receptors for the terminal translocation step of migrating neurons. Moreover, they demonstrated a role for Akt in the regulation of the terminal translocation step, which was rescued by simultaneous coexpression of constitutively active integrin $\alpha 5$ and Akt, but not by either vector alone. It should be mentioned, though, that neuron-specific conditional inactivation of $\beta 1$ integrin using NEX-Cre mice did not affect the formation of cortical cell layers (Belvindrah et al., 2007). A cell-autonomous role of Dab1 phosphorylation at tyrosine residues 220 and 232 for the detachment of neurons from radial glia was shown, which depends on the downregulation of neuronal integrin a3 levels (Sanada et al., 2004). This provides an example for Reelin-dependent inside-out modulation of a cell surface receptor (Figure 2B) by downregulation of its activity.

Jossin and Cooper (2011) showed that Rap1 regulated the membrane localization of $\mathrm{N}$-cadherin, which was required for the transition from multipolar to bipolar migration in the lower intermediate zone. Of note, migration defects of neurons overexpressing a signaling-incompetent, dominant- 
negative (DN) Vldlr construct were only partially rescued by transfection with a constitutively active form of Rap1, whereas coexpression of Akt and activated Rap1 overcame the effect of DN-Vldlr (Jossin and Cooper, 2011). In the marginal zone, Reelin-dependent Rap1 signaling influences the interaction of translocating neurons with Reelin-secreting Cajal-Retzius cells by facilitating Cdh2 recruitment to nectinbased adhesion sites, with the Rap1 effector Afadin and its binding partner p120-Catenin serving as a molecular link between the activation of Rap1 and Cdh2 (Gil-Sanz et al., 2013). However, Cdh2 is not only required for the multipolar-bipolar transition and terminal translocation step of cortical neuronal migration but also involved in mediating heterophilic interactions of migrating neurons with radial glia during the locomotion mode of migration, which depends on the regulation of vesicle trafficking by Rab GTPase proteins (Kawauchi et al., 2010). The importance of Rap 1 is underlined by the phenotype of conditional knockout mice, which show a complete loss of cortical lamination as a consequence of the loss of radial glial and neuronal polarity (Shah et al., 2016). Knockdown of the RasGAP Dab2IP, a Dab1-interacting protein (Homayouni et al., 2003), has been reported to influence the positioning of later-born cortical neurons by activating Rap1 and integrin signaling (Qiao and Homayouni, 2015), and to regulate the multipolar-bipolar transition in the intermediate zone (Lee et al., 2012). However, no complete reeler-like phenotype was reported for conventional Dab2IP (AIP1) knockout mice (Zhang et al., 2008). Other small GTPases like Cdc42 and possibly Rac1 are involved in more specific functions of Reelin during the differentiation of postmitotic neurons (Leemhuis et al., 2010; Jossin, 2011; Leemhuis and Bock, 2011; Meseke et al., 2013; Pasten et al., 2015), where fine-tuning is achieved by the involvement of various GEFs (Rossman et al., 2005).

\section{Role of Dab1 in Receptor Trafficking}

Dab1 is a protein with several features of an endocytic accessory factor (Merrifield and Kaksonen, 2014) and might therefore be involved in the regulation of receptor trafficking. This cellular function of Dab1 is relevant to understanding important aspects of Reelin signaling via both canonical and non-canonical Reelin receptors. The aminoterminal phosphotyrosine binding/PTB domain preferentially interacts with the non-phosphorylated NPXY tetra-amino-acid motif (Herz et al., 1988; Chen et al., 1990) in the intracellular tails of transmembrane receptors, including Apoer2 and Vldlr but also the amyloid precursor protein family members and integrins (Rice et al., 1998; Trommsdorff et al., 1998; Howell et al., 1999b; reviewed in Stolt and Bock, 2006; Yap and Winckler, 2015), and also mediates membrane localization by interacting with phosphoinositides (Stolt et al., 2003, 2005; Huang et al., 2005; Xu et al., 2005). In addition, it contains a clathrin binding site within the carboxyterminal domain, which is involved in the regulation of cortical development, since mice expressing only one copy of a carboxyterminally truncated, hypomorphic p45 isoform of Dab1 display migration defects of late-born cortical neurons (Herrick and Cooper, 2002). Morimura et al. (2005) reported data from experiments in cortical neurons and heterologous cells suggesting that tyrosine-phosphorylated Dab1 is recruited to the plasma membrane after Reelin stimulation and that phosphorylation of Dab1 initiates intracellular trafficking of Reelin.

Interaction with Dab1 increases cell surface levels and proteolytic processing of Apoer2 and APP independent of its tyrosine phosphorylation and increases cleavage of extracellular receptor domains (Hoe et al., 2006b). Interaction of tyrosine-phosphorylated Dab1 with the endocytic adapter protein CIN85 in Reelin-treated neurons might contribute to the sorting of Dab1-receptor complexes to early endosomes (Fuchigami et al., 2013). Another regulator of endosomal receptor cycling, sorting nexin 17 (Snx17), binds to the intracellular domain of lipoprotein receptors including Apoer2 (Stockinger et al., 2002), and was reported to contribute to Reelin-induced Apoer2 trafficking, processing and Dab1 dependent signaling (Sotelo et al., 2014). It should be mentioned that based on studies in heterologous cells it was also suggested that Dab1 has two nuclear localization signals (NLS) and two nuclear export signals (Honda and Nakajima, 2006, 2016) and could therefore act as a nucleocytoplasmic shuttling protein. Tyrosine phosphorylation did not affect the intracellular distribution of Dab1 (Honda and Nakajima, 2006), arguing against a direct role of Dab1 in mediating Reelin-dependent regulation of transcription (Telese et al., 2015). In utero electroporation of Dab1 harboring a mutant NLS confirmed that excess cytoplasmic Dab1 inhibits neuronal migration (Honda and Nakajima, 2016).

\section{Crosstalk with p35/Cdk5 Signaling}

Together, the above-mentioned studies provide important clues about the molecular mechanisms of Reelin's contributions to different steps of neuronal layer formation in the developing neocortex. However, issues such as the the specific contribution of Reelin effectors in different responsive cell types, and the interaction with other signaling pathways (Figure 2F) are still insufficiently understood. Activation of Rap1 constitutes an example of signaling crosstalk with Cyclin-dependent kinase 5 (Cdk5) that is fairly well examined. Cdk5 is a serine/threonine kinase that is highly expressed in postmitotic neurons. Its essential role during brain development is obvious from the phenotype of $C d k 5$ knockout mice, which display severe defects in laminated brain structures. Like Reelin, Cdk5 also modulates many aspects of neuronal maturation and synaptic transmission in the adult brain (reviewed by Dhavan and Tsai, 2001; Kawauchi, 2014; Shah and Lahiri, 2014). However, in contrast to reeler mice, the preplate splits normally during neocortical development (Gilmore et al., 1998), and the failure of Reelin to induce Cdk5 activation (Gilmore et al., 1998) as well as a series of genetic studies support the concept that Reelin and Cdk5 act in parallel rather than in a linear fashion to regulate layer formation in the developing brain (Ohshima 
et al., 2002; Beffert et al., 2004; Ohshima, 2015). Rap1 has been shown to be an important convergence point of both pathways. Whereas RapGEF1 (C3G) is activated by Reelin, RapGEF2 is phosphorylated and thereby activated by Cdk5 at Ser1124, which seems to be important for the transition from multipolar to bipolar morphology in the intermediate zone (Ye et al., 2014). Other possible intersection points of Reelin and Cdk5 signaling include collapsin response mediator proteins (CRMP), whose phosphorylation by the Reelin target Gsk3beta (Beffert et al., 2002) needs to be primed by prior Cdk5 phosphorylation (Uchida et al., 2005; Cole et al., 2006); the microtubule-associated phosphoprotein Tau (Sengupta et al., 1997; Li et al., 2006; Plattner et al., 2006), which is involved in the pathogenesis of neurodegenerative disease, and Dab1 itself (Keshvara et al., 2002; Ohshima et al., 2007), although evidence for the in vivo relevance of these interaction nodes is sparse. Expression of a carboxyterminally truncated form of Dab1 that lacks the Cdk5 phosphorylation sites rescues the Dab1 knockout phenotype, but mice hemizygous for the truncated gene $\left(D a b 1^{\mathrm{p} 45 /-}\right)$ display a unique migration defect in the neocortex, with normal preplate splitting as in the Cdk5 knockout mice, and hippocampus (Herrick and Cooper, 2002).

\section{Non-Canonical Reelin Signaling Involving Apoer2/Vldlir, or Dab1}

Noncanonical signaling can refer to the involvement of components other than Apoer2/Vldlr as cell surface receptors or Dab1 as intracellular signal transducer of Reelin, which are the essential components of the "classical" Reelin cascade, as outlined above. Indeed, several studies have been published that suggest a role for Reelin binding to its canonical receptors Apoer2 and/or Vldlr without involving Dab1 as the central intracellular mediator of this interaction. Other studies point to a requirement of Dab1 for the transmission of the Reelin signal without the involvement of Apoer2 or Vldlr (Figures 2D,E). Rossel et al. (2005) reported that Reelin is required for the second, radial glia-dependent migration step of hindbrain efferent neurons. This phenotype was also observed in Dab1-deficient scrambler mice but not in Apoer2/Vldlr-deficient mice, pointing to the involvement of another receptor for Reelin. Possible candidates would be transmembrane proteins that interact with Dab1 via their intracellular tails, e.g., integrins or amyloid precursor protein.

Conversely, a Reelin-dependent effect on the migration of early-generated interneurons in the olfactory bulb was described, which was defective in lipoprotein receptor-deficient mice but was not phenocopied in mice lacking Dab1 (Hellwig et al., 2012), suggesting that context-dependent alternative signal transduction mechanisms for Reelin exist. Still another scenario was described for hypothalamic gonadotropin releasing hormone $(\mathrm{GnRH})$-positive neurons, with a reduction in number and aberrant position of $\mathrm{GnRH}$ neurons in the hypothalamus of reeler, but not Dab1 or Apoer2/Vldlrdeficient neurons (Cariboni et al., 2005). A similar situation is found during lymphatic vascular development, which is defective in Reelin-deficient reeler mice but not in mice lacking Dab1 or both Apoer2 and Vldlr (Lutter et al., 2012). In none of these cases, the molecular mechanisms underlying the described Reelin-dependent phenotypes have been elucidated.

\section{Reelin-Independent Activation of Lipoprotein Receptor-Dab1 Dependent Signaling}

Another "non-canonical" variation of classical Reelin signaling is the activation of the core signaling pathway by ligands other than Reelin itself. Reelin has been described to be important for the so-called chain migration of neuroblasts from the subventricular zone into the olfactory bulb along the rostral migratory stream (RMS; Hack et al., 2002). Here, Reelin induces the detachment of chain-migrating neurons, leading to a switch from chain migration to radial migration in the olfactory bulb. Apoer2 and Dab1 are expressed in the RMS, and Apoer2 and Vldlr seem to be involved in mediating the effect of Reelin on the detachment process (Hellwig et al., 2012). Because Reelin is not present in the RMS (Hack et al., 2002; Andrade et al., 2007), it was suggested that the involvement of Apoer2/Vldlr and Dab1 for proper neuroblast chain formation indicates the requirement for another lipoprotein receptor ligand (Andrade et al., 2007). Since the extracellular matrix (ECM) protein thrombospondin-1 (Tsp1) is expressed in the RMS and Tsp1-deficient mice have a wider and less compact RMS architecture it was examined whether Tsp1 might act as a ligand for Apoer2 and Vldlr, which was shown to be the case (Blake et al., 2008). Tsp1 binding to the receptors was competitive to both Reelin and receptor-associated protein (RAP), a chaperone and universal ligand for LDL receptor family members (Herz et al., 1991), and treatment with Tsp1 induced the tyrosine phosphorylation of Dab1 in primary neurons, probably by promoting receptor multimerization (Blake et al., 2008). Surprisingly, however, other key features of canonical Reelin signaling, such as ligand-induced Dab1 degradation were not observed, and in an in vitro-based matrigel assay Tsp1 stabilized neuronal precursor chains (Blake et al., 2008), instead of dissolving them like Reelin does (Hack et al., 2002). The molecular basis of these differences in downstream signaling via Apoer2 and Dab1 remains to be identified and might involve differences in the phosphorylation of the various Dab1 tyrosyl residues, or the different activation of modulating signaling pathways by coreceptors. Another ECM protein that has been reported to bind to Apoer2 was F-spondin (Hoe et al., 2005). The interaction site was mapped to the aminoterminal thrombospondin domains of F-spondin, which are located in the carboxyterminal half of the protein, and was inhibited by the LDL receptor family chaperone RAP, whereas the aminoterminal Reelin and spondin domains bound to the amyloid precursor protein (APP). These interactions were reported to increase the cell surface expression of both receptors and modulated their proteolytic processing (Ho and Sudhof, 2004; Hoe et al., 2005). In chicken ciliary ganglion (CG) neurons, F-spondin induced tyrosine phosphorylation 
of Dab1 (Peterziel et al., 2011). Surprisingly, this was likely mediated through binding of F-spondin to APP (Figure 2D), since Apoer2 and Vldlr were barely expressed in the GC cells, and the lipoprotein receptor antagonist RAP did not block the neurotrophic effect of F-spondin on GC cells, which was shown to depend on Dab1 phosphorylation (Peterziel et al., 2011).

In another study that was based on the observation of an olfactory bulb layering defect in insulin-like growth factor 1 (IGF1)-deficient mice an effect of IGF1 on Dab1 phosphorylation in OB cell cultures was reported (Hurtado-Chong et al., 2009). However, the phosphosite-specific Dab1 antibodies used in this study were confirmed for overexpresssing cells only and are not specific in primary cortical cultures, and the results should therefore be validated by Dab1 immunoprecipitation followed by phosphotyrosine immunoblotting, or by using $\mathrm{OB}$ cells from Dab1-deficient animals. Other ligands that have been described to induce tyrosine phosphorylation of Dab1 via lipoprotein receptor-dependent signaling include fibrillar prion protein fragment, which also reduces total Dab1 levels after prolonged treatment (Gavín et al., 2008), and clusterin/apolipoprotein $\mathrm{J}$, which is present in the adult subventricular zone and might be involved in neurogenesis and neuroblast chain formation (Leeb et al., 2014). Another effect mediated by Apoer2 which does not depend on Reelin was described in the monocytic cell line U937: Activated protein C (APC) induced Dab1 tyrosine phosphorylation and Akt-dependent Gsk3beta phosphorylation in a RAPsensitive manner (Yang et al., 2009; Sinha et al., 2016), which contributed to APC's anticoagulant activity after endotoxin stimulation in vitro. Vldlr did not bind to APC as determined by surface plasmon resonance or solidphase binding assays (Yang et al., 2009). It remains to be determined if Reelin, which is present in large amounts in the plasma (Smalheiser et al., 2000), has similar effects on circulating blood cells. Vascular endothelial growth factor (VEGF)-induced tyrosine phosphorylation of Dab1 mediated by the receptor tyrosine kinase Flk1 (VEGF receptor-2) in cortical neurons has been reported using a phosphospecific DAB1 antibody (Howell et al., 2013). Again, this finding should be confirmed by Dab1 immunoprecipitation followed by immunoblotting with a phosphotyrosine antibody.

It should be mentioned that selenoprotein P (Sepp1) has been described as an Apoer2 ligand that does not interfere with canonical lipoprotein receptor-Dab1 signaling. Instead, its endocytosis via Apoer2 is essential for selenium supply in the brain and testis (Olson et al., 2007; Masiulis et al., 2009), and is mediated by the Apoer2 beta-propeller domain instead of the ligand binding domain (Kurokawa et al., 2014). Another Apoer2 and Vldlr ligand, the proprotein convertase Pcsk9, binds to the epidermal growth factor-like repeat A of LDL receptor family members next to the ligand binding domain and mediates the intracellular degradation of both receptors by rerouting them to a lysosomal pathway (Cohen and Hobbs, 2013). Whereas this effect was enhanced by the presence of Dab1 in heterologous cells (Poirier et al., 2008), its physiological relevance for Reelin signaling in the brain is unclear (Liu et al., 2010; Kysenius et al., 2012).

\section{Selective Functions of the Canonical Reelin Receptors Apoer2 and VIdIr}

Apoer2 and Vldlr are close relatives of the LDL receptor and share a high degree of homology, although important structural differences exist, which are reviewed elsewhere (Bock and Herz, 2008; Reddy et al., 2011). Both receptors bind Reelin as high-affinity receptors, with slightly different binding affinities (Andersen et al., 2003; Benhayon et al., 2003), and can mediate tyrosine phosphorylation of Dab1 as well as activation of Dab1-dependent downstream targets like Akt without the requirement of the presence of the other receptor, as was first shown by using cultured cortical neurons from either Apoer2 or Vldlr single-knockout mice (Beffert et al., 2002). However, the single-knockout mice display strikingly different phenotypes (e.g., Trommsdorff et al., 1999; Weeber et al., 2002; Hack et al., 2007), which is largely explained by the non-overlapping spatiotemporal and subcellular expression pattern of both receptors (Perez-Garcia et al., 2004; Hirota et al., 2015). In addition, differences exist with regard to the subcellular distribution, especially the recruitment to cholesterolrich microdomains of the plasma membrane (Sun and Soutar, 2003; Mayer et al., 2006), which have important functions in regulating signal transduction and receptor trafficking (reviewed in Lingwood and Simons, 2010). Also, differences in their capacity to mediate endocytosis and degradation of bound ligands likely contribute to their different biological functions (Li et al., 2001; Beffert et al., 2006a; Chen et al., 2010; Duit et al., 2010). Another possible mechanism would be the receptorspecific interaction with different adapter proteins. Important aspects of Apoer2's function as Reelin receptor depend on its differential splicing. The O-linked sugar domain of Apoer2 in close proximity of the transmembrane domain is encoded by a separate exon and required for the extracellular cleavage of Apoer2, which precedes its gamma-secretase mediated proteolytic processing (May et al., 2003b). Mice lacking this exon showed increased Apoer2 abundance in the brain, which was associated with altered synaptic receptor function (Wasser et al., 2014). Activity-dependent alternative splicing of the intracellular exon 19 of Apoer2, which encodes a proline-rich insert that mediates biochemical and functional interaction with NMDA receptors at the synapse (Beffert et al., 2005; Hoe et al., 2006a), represents an additional important means to fine-tune biological responses to Reelin signaling in a context-dependent manner. Scaffold proteins of the JIP and MINT families also bind to Apoer2, but not to Vldlr (Figure 2E), in an exon 19-dependent manner (Gotthardt et al., 2000; Stockinger et al., 2000; Verhey et al., 2001; He et al., 2007; Minami et al., 2010). The JIP-JNK recruiting function of the Apoer2 isoform including the prolinerich insert is required for protection against loss of corticospinal neurons (CSN) during normal aging, whereas the same splice form promotes lesion-induced cell death of CSN, as was elegantly shown in vivo by using knockin mice with selective alterations of the Apoer2 intracellular domain (Beffert et al., 2006b). 
The Dab1 binding site was not involved, suggesting Reelin signaling-independent functions of the Apoer2 intracellular domain. Direct phosphorylation of JNK was demonstrated in hippocampal neurons treated for $1 \mathrm{~h}$ with recombinant Reelin. This was blocked by either PI3K inhibition or pertussis toxin, suggesting involvement of heterotrimeric $G$ protein and crosstalk with G-protein coupled receptor signaling (Cho et al., 2015).

On the other hand, Vldlr-specific Reelin signaling responses (Figure 2E) have been described. Following demonstration that Reelin and LIS1, the gene product of the Pafah1b1 gene, genetically and biochemically interact in a phosphoDab1-dependent manner (Assadi et al., 2003) it was shown that the $\alpha 1$ and $\alpha 2$ catalytic subunits of the Pafahb complex selectively bind the NPXYL motif in the intracellular Vldlr domain (Zhang et al., 2007) and differentially interact with either tyrosine phosphorylated or non-phosphorylated Dab1, which modulates the effect of Reelin-Dab1-Lis1 signaling on microtubule dynamics (Assadi et al., 2008; Zhang et al., 2009). In a recent study, it was reported that Vldlr-dependent Ras signaling affects dendritic spine formation in hippocampal neurons (DiBattista et al., 2015). The authors used a recombinant Reelin fragment, which decreased the biochemical interaction of Vldlr with the GEF RasGRF1; however, it remains to be determined if full-length Reelin exerts the same effect.

The same murine Reelin fragment encompassing amino acids 1221-2661 (i.e., corresponding to the central fragment consisting of the Reelin repeats 3-6 that is able to bind to Apoer2 and Vldlr and to induce Dab1 phosphorylation in cultured neurons (Jossin et al., 2004)) was used to demonstrate coclustering of Apoer2 with other receptors (Divekar et al., 2014). This fragment includes a critical cysteine residue at position 2101 that is required for covalent multimerization and efficient Dab1 phosphorylation (Yasui et al., 2011). Coprecipitation of Apoer2 and Vldlr after stimulation with the Reelin fragment was not observed in heterologous cells and primary neurons, leaving open the question if Reelin induces its two main receptors to form heteroclusters to a significant extent.

\section{Activation of Pathways that Modulate Transcription}

Another pivotal protein kinase cascade that relays extracellular signals from the cell surface into cells is the Erk (extracellular signal-regulated kinases) pathway, which was reported to be activated by Reelin in a Src- and Dab1-dependent manner (Simó et al., 2007). Whereas other studies could not detect Erk phosphorylation after stimulation with Reelin-conditioned medium (Ballif et al., 2003; Cho et al., 2015), the activation of Erk in primary neurons was confirmed using highly purified Reelin (Lee et al., 2014; Telese et al., 2015). In contrast to the aforementioned study (Simó et al., 2007), this activation did not depend on Dab1 and was not inhibited by recombinant RAP, a chaperone that blocks binding of extracellular ligands to LDL receptor family members, which suggests involvement of a different Reelin receptor. This is supported by the observation that the lipoprotein receptor-binding central fragment of Reelin was not sufficient to induce Erk phosphorylation (Lee et al.,
2014). Reelin-induced Erk activation was accompanied by increased transcription of immediate early genes including Egr1 and Arc (Simó et al., 2007; Lee et al., 2014). In addition, it was demonstrated that Reelin directly potentiates glutamate-induced NMDA receptor-dependent calcium influx (Chen et al., 2005). This was mediated via activation of Src kinases, Dab1 and NMDAR phosphorylation and induced the phosphorylation of cAMP-responsive element binding protein (Creb) at serine 133 (Chen et al., 2005), a transcription factor that modulates many aspects of neuronal development, plasticity and behavior in response to PI3K/Akt and Erk activation (Lonze and Ginty, 2002). Together, these findings suggested that regulation of gene transcription contributes to Reelin's multiple effects on brain development and function. Indeed, transcriptomic profiling of mature cortical neurons confirmed that Reelin induces the expression of synaptic activity-regulated genes in a Src- and NMDAR-dependent manner (Telese et al., 2015). This involved Reelin-induced epigenomic changes that were sensitive to gamma-secretase inhibition, possibly involving nuclear translocation of the intracellular domain of Apoer2 (Telese et al., 2015), which is released by gamma-secretase activity in neurons (May et al., 2003b; Hoe and Rebeck, 2005; Wasser et al., 2014).

Another means of gamma-secretase dependent transcriptional regulation involving Reelin is its crosstalk with Notch signaling, a pathway that regulates many aspects of neural development, cell fate specification, neuronal survival and synaptic plasticity (reviewed by Ables et al., 2011; Pierfelice et al., 2011). A link between Notch and Disabled was first shown in Drosophila (Giniger, 1998). In mice, activation of Notch receptors leads to the gamma-secretase mediated release and nuclear localization of their intracellular domains (NICD), which regulates the transcription of target genes. In reeler mice, levels of the NICD and its target genes Hes 1 and Hes5 were reduced, and overexpression of the NICD by electroporation rescued the neuronal migration defect in reeler mice or caused by overexpression of the Dab1-5F mutant, which cannot be tyrosine-phosphorylated at Y185, Y198/200, Y220 and Y232 (Hashimoto-Torii et al., 2008). This places NICD, which biochemically interacts with Dab1 (Hashimoto-Torii et al., 2008; Keilani and Sugaya, 2008), downstream of Dab1. Apart from its effect on neocortical migration, the interaction of Reelin and Notch affects the radial glial characteristics of progenitor cells (Keilani and Sugaya, 2008; Sibbe et al., 2009; Lakomá et al., 2011), including expression of brain lipid binding protein (Blbp), an effector of both pathways (Gaiano et al., 2000; Hartfuss et al., 2003). In a recent study it was shown that both Erk and Creb phosphorylation are reduced in the hippocampi of conditional Notch1-deficient mice, and suggested that Notch1 is also required for NMDAR-mediated Reelin signaling at the synapse (Brai et al., 2015).

\section{Non-Canonical Reelin Receptors}

The inside-out activation of integrin receptors by Reelin-Dab1Crk-Rap1 dependent signaling has been discussed above; here, integrin transmembrane proteins act as downstream effectors 
of Reelin signaling via the canonical lipoprotein receptor-Dab1mediated pathway (Sekine et al., 2012). Direct binding of Reelin via its aminoterminal region to the extracellular domain of $\alpha 3$ $\beta 1$ integrins has also been shown (Dulabon et al., 2000; Schmid et al., 2005). In addition, Dab1 interacts with the NPXY motif in the cytoplasmic tails of beta integrins (Calderwood et al., 2003; Schmid et al., 2005). In $\alpha 3 \beta 1$ integrin-deficient cortical neurons Reelin-induced phosphorylation was not affected, but interestingly, Dab1 levels were downregulated in $\alpha 3$ integrindeficient brains (Dulabon et al., 2000), as opposed to the characteristic upregulation of Dab1 in mice with genetic defects in the canonical lipoprotein receptor-dependent Reelin signaling cascade (see above). The preplate forms normally in the cortex of $\alpha 3$-deficient mice (Schmid et al., 2004), whereas inactivation of $\beta 1$ integrin in radial glial cells, which are both neural and glial progenitor cells (reviewed by Dimou and Götz, 2014), develop a disorganized cortex with Cajal-Retzius cell heterotopia (Graus-Porta et al., 2001). Neuron-specific inactivation of $\beta 1$ integrin produced no phenotype (Belvindrah et al., 2007), which suggests that Reelin-integrin binding alone is not responsible for the neuronal migration defect seen in reeler mice (Magdaleno and Curran, 2001) and that $\beta 1$ integrin expression is pivotal for radial glial function (Forster et al., 2002; Radakovits et al., 2009).

Chronic treatment of hippocampal neurons with Reelin altered the subunit composition of synaptic NMDA receptors, which involved $\beta 1$ integrin activity as shown by using functionblocking antibodies. The lipoprotein receptor antagonist RAP had no effect (Groc et al., 2007), ruling out inside-out activation of integrins via lipoprotein receptors as underlying signaling mechanism. Moreover, a presynaptic effect of Reelin on neurotransmitter release, which was blocked by a cyclic integrininhibiting arginylglycylaspartic acid (RGD) peptide (Ruoslahti, 1996), has been reported (Hellwig et al., 2011). In mouse brain synaptosome preparations Reelin enhanced the local translation of Arc mRNA (Dong et al., 2003), an immediate early gene that regulates synaptic plasticity (Shepherd and Bear, 2011), and this was inhibited by echistatin, an RGDcontaining peptide that functions as a competitive integrin receptor antagonist (Gan et al., 1988). Hence, integrins might modulate the functions of Reelin at the synapse. However, a selective increase of spontaneous neurotransmission by Reelin was reported to depend both on Vldlr and Apoer2, which was also expressed presynaptically, and PI3 kinase activity, and required the vesicular SNARE protein Vamp7 (Bal et al., 2013). Apart from brain-specific roles, integrins are prime candidate receptors for Reelin functions in "peripheral" organs (Lin et al., 2016), many of which do not express detectable amounts of essential components of the canonical signaling cascade.

\section{Reelin as a Ligand for Amyloid Precursor Protein (APP)}

The demonstration that the interaction of Reelin with lipoprotein receptors at the adult synapse enhances long-term potentiation through Dab1- and Fyn-dependent phosphorylation of NMDA receptors (Weeber et al., 2002; Beffert et al., 2005; Chen et al., 2005) suggested that Reelin signaling in the adult brain modulates learning and memory performance, which has subsequently been demonstrated in vivo using different experimental approaches including conditional knockout of Reelin, Dab1, or Reelin overexpression in adult mice (Brosda et al., 2011; Rogers et al., 2011, 2013; Trotter et al., 2013; Pujadas et al., 2014; Lane-Donovan et al., 2015; Imai et al., 2016). As LDL receptor family members are main receptors for Apo E (reviewed by Herz and Willnow, 1994; Hussain et al., 1999), whose $\mathrm{E} 4$ variant is a strong genetic risk factor for the sporadic form of Alzheimer disease (AD; (Strittmatter et al., 1993), a causal connection between disturbed Reelin signaling and neurodegeneration has been proposed ever since Apoer2 and Vldlr were first described as Reelin receptors (Cooper and Howell, 1999; Bothwell and Giniger, 2000; Herz, 2001). This view, summarized in several reviews (e.g., Rogers and Weeber, 2008; Krstic et al., 2013; LaneDonovan et al., 2014) is supported by a multitude of in vitro and in vivo studies, which collectively suggest that Reelin has an overall neuroprotective role in the adult brain. The amyloid-beta peptide, which is considered to be central for the development and progression of $\mathrm{AD}$ (Selkoe, 2000), is generated by sequential proteolytic cleavage from a type I transmembrane receptor named APP (O'Brien and Wong, 2011). Importantly, the inhibition of hippocampal long-term potentiation (LTP) by soluble amyloid-beta oligomers (reviewed by Selkoe, 2008) is overcome by coapplication of Reelin in acute slices (Durakoglugil et al., 2009), and selective retardation of cell surface recycling of endocytosed ReelinApoE receptor complexes by ApoE4-containing lipoproteins at least partially explains the negative effect of this isoform on synaptic function (Chen et al., 2010). Inactivation of Reelin in the adult brain by tamoxifen-inducible conditional gene knockout precipitated amyloid-beta neurotoxicity in transgenic mice overexpressing an $\mathrm{AD}$-associated mutant form of APP (Lane-Donovan et al., 2015). In a reverse approach, inducible overexpression of Reelin was shown to overcome toxic effects of amyloid-beta (Pujadas et al., 2014). In this study, Reelin delayed the formation of amyloid fibrils, the main constituents of senile plaques, which were previously shown to accumulate Reelin both in animal models of $\mathrm{AD}$ and during normal aging (Wirths et al., 2001; Knuesel et al., 2009). Importantly, however, loss of Reelin in the conditional knockout model did not accelerate amyloid plaque deposition at the studied age of 7 months (Lane-Donovan et al., 2015). This rules out the possibility that Reelin's protective role at the synapse is predominantly mediated by regulating plaque abundance.

Beside its function as a preproprotein whose processing generates biologically active soluble fragments (Haass et al., 2012) and a transcriptionally active intracellular domain (Müller et al., 2008) the role of the full-length amyloid precursor protein as a cell surface receptor is being increasingly recognized (Deyts et al., 2016), although its normal physiological functions remain largely unknown. Reelin has been reported to be one of several candidate ligands of full-length APP (Hoe et al., 2009) and modulates the proteolytic processing of APP in vivo and in vitro (Kocherhans 
et al., 2010; Rice et al., 2013), partly through the interaction of APP with Dab1 (Rice et al., 1998; Trommsdorff et al., 1998; Howell et al., 1999b), Fe65, and lipoprotein receptors (Hoe et al., 2006b, 2008; Parisiadou and Efthimiopoulos, 2007; Kwon et al., 2010; Minami et al., 2011). The direct binding of Reelin to the extracellular domain of APP involves its central fragment, which also interacts with the ligand binding domains of Apoer2 and Vldlr (Hoe et al., 2009). A possible function of this interaction, which was reported to involve $\alpha 3 \beta 1$ integrins, might be the regulation of neurite outhgrowth (Hoe et al., 2009). An excess of the APP intracellular domain blocked the inhibitory effect of cell surface-immobilized Reelin on neurite outgrowth, possibly by sequestering Dab1 in the nucleus (Hoareau et al., 2008). The genetic interaction of Dab1 and App, and the effect of App knockdown or overexpression on neuronal migration (YoungPearse et al., 2007; Pramatarova et al., 2008) support additional functions for Reelin-APP and APP-Dab1 interactions during neurodevelopment.

\section{Interaction with Eph Receptors}

Mice lacking members of the EphB transmembrane tyrosine kinase receptor family, which mediate a variety of interactions regulating brain development and function (reviewed by Klein, 2004; North et al., 2013), display deficits in hippocampal morphogenesis (Catchpole and Henkemeyer, 2011; Bouché et al., 2013). This observation led to the identification of EphB proteins as Reelin receptors. Binding to the extracellular domain of EphB2 is mediated by the aminoterminal part of Reelin and induces EphB forward signaling (Figure 2D) in heterologous cells expressing EphB2 and in primary neurons (Bouché et al., 2013). Principally, the interaction with the aminoterminal domain of Reelin allows for the simultaneous binding of lipoprotein receptors or APP, which interact with Reelin via its central fragment. The composition of the putative supramolecular Reelin-receptor complex might be further modulated through regulated proteolytic cleavage of Reelin (Lambert de Rouvroit et al., 1999; Jossin et al., 2007; Kohno et al., 2009; Krstic et al., 2012; Tinnes et al., 2013; Koie et al., 2014; Trotter et al., 2014; Sato et al., 2016) and gamma-secretase dependent intramembrane proteolysis of its receptors (Haass and De Strooper, 1999; May et al., 2003b; Hoe and Rebeck, 2005, 2008; Litterst et al., 2007; Xu et al., 2009; Bouché et al., 2013; Wasser et al., 2014), which opens up new avenues of crosstalk with other important neuronal signaling receptor systems (Larios et al., 2014).

Whereas the hippocampal defect in EphB1; EphB2 compound deficient mice that could be attributable to defective Reelinmediated EphB forward signaling is limited to the CA3 region, other functions of this non-canonical Reelin-receptor interaction in the central nervous system might relate to the positioning of Cajal-Retzius cells by EphB-dependent contact repulsion during brain development (Villar-Cerviño et al., 2013), or the finetuning of NMDA receptor signaling at the synapse (Cissé et al., 2011; Nolt et al., 2011). The interaction might also be relevant to organs and tissues outside of the nervous system (Jung et al., 2011).

\section{SUMMARY AND PERSPECTIVE}

The discovery of the canonical linear lipoprotein receptor/Dab1dependent Reelin signaling cascade has enabled us to decipher many of the cellular and molecular mechanisms underlying Reelin's multiple functions in the developing and adult brain, and is now one of the best-characterized signaling pathways involved in shaping the developing brain (Ayala et al., 2007). However, even for well-established Reelin targets, many open questions regarding their exact functional relevance remain, which can be attributed to the pleiotropic actions of Reelin at different stages of development, different Reelinresponsive cells, different requirements for specific Reelin domains depending on the developmental stage (Kohno et al., 2015), functional redundancies of signaling components, posttranslational modifications of Reelin (Botella-López et al., 2006), and various technical obstacles (Baek et al., 2014). The biological functions of non-canonical Reelin signaling cascades, as outlined in detail above, are even less well defined and require further investigation.

Many of the non-canonical Reelin-receptor interactions are possibly related to the expression of Reelin outside the brain, which has first been acknowledged shortly after the Reelin gene was discovered (Ikeda and Terashima, 1997). Various tissues and organs contain Reelin at relatively high concentrations, including plasma, blood cells, liver and intestine (Smalheiser et al., 2000; Lugli et al., 2003; Underhill et al., 2003; García-Miranda et al., 2010; Böttner et al., 2014; Ding et al., 2016), and altered expression, glycosylation and processing of peripheral Reelin under pathophysiological conditions has been described (BotellaLopez et al., 2008). Moreover, an association of (mostly reduced) Reelin expression and malignancy of various tumors has been reported, even in tissues that normally do not express Reelin, which suggests a possible role in the control of tumorigenesis and/or metastasis via unknown mechanisms (Wang et al., 2002; Sato et al., 2006; Perrone et al., 2007; Dohi et al., 2010; Stein et al., 2010; Okamura et al., 2011; Castellano et al., 2016; Lin et al., 2016). In many of these tissues the canonical mediators of Reelin signal transduction are not expressed, whereas interactions of hitherto unknown significance, such as low-affinity binding to the LDL receptor (D'Arcangelo et al., 1999), might turn out to be of physiological significance and hint to as yet unknown or poorly defined functions of Reelin that might be unrelated to signaling, e.g., sequestering of coagulation factors (Tseng et al., 2014).

\section{AUTHOR CONTRIBUTIONS}

HHB and PM: designed, wrote and approved the review.

\section{FUNDING}

Work in the laboratory of HHB and PM is supported by the Bundesministerium für Bildung und Forschung (BMBF) (ReelinSys, 0316174C) and the Deutsche Forschungsgemeinschaft (DFG) (SFB974/B10). 


\section{REFERENCES}

Ables, J. L., Breunig, J. J., Eisch, A. J., and Rakic, P. (2011). Not(ch) just development: notch signalling in the adult brain. Nat. Rev. Neurosci. 12, 269-283. doi: 10.1038/nrn3024

Andersen, O. M., Benhayon, D., Curran, T., and Willnow, T. E. (2003). Differential binding of ligands to the apolipoprotein E receptor 2. Biochemistry 42, 9355-9364. doi: 10.1021/bi034475p

Andrade, N., Komnenovic, V., Blake, S. M., Jossin, Y., Howell, B., Goffinet, A., et al. (2007). ApoER2/VLDL receptor and Dab1 in the rostral migratory stream function in postnatal neuronal migration independently of Reelin. Proc. Natl. Acad. Sci. U S A 104, 8508-8513. doi: 10.1073/pnas.0611391104

Arnaud, L., Ballif, B. A., and Cooper, J. A. (2003a). Regulation of protein tyrosine kinase signaling by substrate degradation during brain development. Mol. Cell. Biol. 23, 9293-9302. doi: 10.1128/mcb.23.24.9293-9302.2003

Arnaud, L., Ballif, B. A., Förster, E., and Cooper, J. A. (2003b). Fyn tyrosine kinase is a critical regulator of disabled-1 during brain development. Curr. Biol. 13, 9-17. doi: 10.1016/s0960-9822(02)01397-0

Assadi, A. H., Zhang, G., Beffert, U., McNeil, R. S., Renfro, A. L., Niu, S., et al. (2003). Interaction of reelin signaling and Lis1 in brain development. Nat. Genet. 35, 270-276. doi: 10.1038/ng1257

Assadi, A. H., Zhang, G., McNeil, R., Clark, G. D., and D'Arcangelo, G. (2008). Pafah1b2 mutations suppress the development of hydrocephalus in compound Pafah1b1; Reln and Pafah1b1; Dab1 mutant mice. Neurosci. Lett. 439, 100-105. doi: 10.1016/j.neulet.2008.04.096

Ayala, R., Shu, T., and Tsai, L. H. (2007). Trekking across the brain: the journey of neuronal migration. Cell 128, 29-43. doi: 10.1016/j.cell.2006.12.021

Baek, S. T., Copeland, B., Yun, E. J., Kwon, S. K., Guemez-Gamboa, A., Schaffer, A. E., et al. (2015). An AKT3-FOXG1-reelin network underlies defective migration in human focal malformations of cortical development. Nat. Med. 21, 1445-1454. doi: 10.1038/nm.3982

Baek, S. T., Kerjan, G., Bielas, S. L., Lee, J. E., Fenstermaker, A. G., Novarino, G., et al. (2014). Off-target effect of doublecortin family shRNA on neuronal migration associated with endogenous microRNA dysregulation. Neuron 82, 1255-1262. doi: 10.1016/j.neuron.2014.04.036

Bal, M., Leitz, J., Reese, A. L., Ramirez, D. M., Durakoglugil, M., Herz, J., et al. (2013). Reelin mobilizes a VAMP7-dependent synaptic vesicle pool and selectively augments spontaneous neurotransmission. Neuron 80, 934-946. doi: 10.1016/j.neuron.2013.08.024

Ballif, B. A., Arnaud, L., and Cooper, J. A. (2003). Tyrosine phosphorylation of Disabled-1 is essential for Reelin-stimulated activation of Akt and Src family kinases. Brain Res. Mol. Brain Res. 117, 152-159. doi: 10.1016/s0169328x(03)00295-x

Ballif, B. A., Arnaud, L., Arthur, W. T., Guris, D., Imamoto, A., and Cooper, J. A. (2004). Activation of a Dab1/CrkL/C3G/Rap1 pathway in reelin-stimulated neurons. Curr. Biol. 14, 606-610. doi: 10.1016/j.cub.2004.03.038

Bar, I., Tissir, F., Lambert de Rouvroit, C., De Backer, O., and Goffinet, A. M. (2003). The gene encoding disabled-1 (DAB1), the intracellular adaptor of the Reelin pathway, reveals unusual complexity in human and mouse. J. Biol. Chem. 278, 5802-5812. doi: 10.1074/jbc.M207178200

Beffert, U., Durudas, A., Weeber, E. J., Stolt, P. C., Giehl, K. M., Sweatt, J. D., et al. (2006a). Functional dissection of Reelin signaling by site-directed disruption of Disabled-1 adaptor binding to apolipoprotein E receptor 2: distinct roles in development and synaptic plasticity. J. Neurosci. 26, 2041-2052. doi: 10. 1523/JNEUROSCI.4566-05.2006

Beffert, U., Nematollah Farsian, F., Masiulis, I., Hammer, R. E., Yoon, S. O., Giehl, K. M., et al. (2006b). ApoE receptor 2 controls neuronal survival in the adult brain. Curr. Biol. 16, 2446-2452. doi: 10.1016/j.cub.2006.10.029

Beffert, U., Morfini, G., Bock, H. H., Reyna, H., Brady, S. T., and Herz, J. (2002). Reelin-mediated signaling locally regulates protein kinase B/Akt and glycogen synthase kinase 3 beta. J. Biol. Chem. 277, 49958-49964. doi: 10.1074/jbc. M209205200

Beffert, U., Weeber, E. J., Durudas, A., Qiu, S., Masiulis, I., Sweatt, J. D., et al. (2005). Modulation of synaptic plasticity and memory by Reelin involves differential splicing of the lipoprotein receptor Apoer2. Neuron 47, 567-579. doi: 10.1016/j.neuron.2005.07.007

Beffert, U., Weeber, E. J., Morfini, G., Ko, J., Brady, S. T., Tsai, L. H., et al. (2004). Reelin and cyclin-dependent kinase 5-dependent signals cooperate in regulating neuronal migration and synaptic transmission. J. Neurosci. 24, 1897-1906. doi: 10.1523/JNEUROSCI.4084-03.2004

Belvindrah, R., Graus-Porta, D., Goebbels, S., Nave, K. A., and Müller, U. (2007). $\beta 1$ integrins in radial glia but not in migrating neurons are essential for the formation of cell layers in the cerebral cortex. J. Neurosci. 27, 13854-13865. doi: 10.1523/JNEUROSCI.4494-07.2007

Benhayon, D., Magdaleno, S., and Curran, T. (2003). Binding of purified Reelin to ApoER2 and VLDLR mediates tyrosine phosphorylation of Disabled-1. Brain Res. Mol. Brain Res. 112, 33-45. doi: 10.1016/s0169-328x(03)00032-9

Blake, S. M., Strasser, V., Andrade, N., Duit, S., Hofbauer, R., Schneider, W. J., et al. (2008). Thrombospondin-1 binds to ApoER2 and VLDL receptor and functions in postnatal neuronal migration. EMBO J. 27, 3069-3080. doi: 10. 1038/emboj.2008.223

Bock, H. H., and Herz, J. (2003). Reelin activates SRC family tyrosine kinases in neurons. Curr. Biol. 13, 18-26. doi: 10.1016/s0960-9822(02)01403-3

Bock, H. H., and Herz, J. (2008). “Apolipoprotein E receptor 2 and very low density lipoprotein receptor: an overview," in Reelin Glycoprotein: Structure, Biology and Roles in Health and Disease, ed. S. H. Fatemi (New York, NY: Springer), 15-35.

Bock, H. H., Jossin, Y., Liu, P., Förster, E., May, P., Goffinet, A. M., et al. (2003). Phosphatidylinositol 3-kinase interacts with the adaptor protein Dab1 in response to Reelin signaling and is required for normal cortical lamination. J. Biol. Chem. 278, 38772-38779. doi: 10.1074/jbc.M306416200

Bock, H. H., Jossin, Y., May, P., Bergner, O., and Herz, J. (2004). Apolipoprotein $\mathrm{E}$ receptors are required for reelin-induced proteasomal degradation of the neuronal adaptor protein Disabled-1. J. Biol. Chem. 279, 33471-33479. doi: 10. 1074/jbc.m401770200

Botella-López, A., Burgaya, F., Gavín, R., García-Ayllón, M. S., Gómez-Tortosa, E., Peña-Casanova, J., et al. (2006). Reelin expression and glycosylation patterns are altered in Alzheimer's disease. Proc. Natl. Acad. Sci. U S A 103, 5573-5578. doi: 10.1073/pnas.0601279103

Botella-Lopez, A., de Madaria, E., Jover, R., Bataller, R., Sancho-Bru, P., Candela, A., et al. (2008). Reelin is overexpressed in the liver and plasma of bile duct ligated rats and its levels and glycosylation are altered in plasma of humans with cirrhosis. Int. J. Biochem. Cell Biol. 40, 766-775. doi: 10.1016/j.biocel.2007.10. 021

Bothwell, M., and Giniger, E. (2000). Alzheimer's disease: neurodevelopment converges with neurodegeneration. Cell 102, 271-273. doi: 10.1016/S00928674(00)00032-5

Böttner, M., Ghorbani, P., Harde, J., Barrenschee, M., Hellwig, I., Vogel, I., et al. (2014). Expression and regulation of reelin and its receptors in the enteric nervous system. Mol. Cell. Neurosci. 61, 23-33. doi: 10.1016/j.mcn.2014.05.001

Bouché, E., Romero-Ortega, M. I., Henkemeyer, M., Catchpole, T., Leemhuis, J., Frotscher, M., et al. (2013). Reelin induces EphB activation. Cell Res. 23, 473-490. doi: 10.1038/cr.2013.7

Brai, E., Marathe, S., Astori, S., Fredj, N. B., Perry, E., Lamy, C., et al. (2015). Notch1 regulates hippocampal plasticity through interaction with the reelin pathway, glutamatergic transmission and CREB signaling. Front. Cell. Neurosci. 9:447. doi: 10.3389/fncel.2015.00447

Brosda, J., Dietz, F., and Koch, M. (2011). Impairment of cognitive performance after reelin knockdown in the medial prefrontal cortex of pubertal or adult rats. Neurobiol. Dis. 44, 239-247. doi: 10.1016/j.nbd.2011.07.008

Brunkhorst, R., Bock, H. H., and Derouiche, A. (2015). Reelin induces process growth in cultured astrocytes: implication for glia-synaptic plasticity. Arch. Ital. Biol. 153, 249-254. doi: 10.12871/00039829201541

Brunne, B., Franco, S., Bouché, E., Herz, J., Howell, B. W., Pahle, J., et al. (2013). Role of the postnatal radial glial scaffold for the development of the dentate gyrus as revealed by Reelin signaling mutant mice. Glia 61, 1347-1363. doi: 10. 1002/glia.22519

Caffrey, J. R., Hughes, B. D., Britto, J. M., and Landman, K. A. (2014). An in silico agent-based model demonstrates Reelin function in directing lamination of neurons during cortical development. PLoS One 9:e110415. doi: 10.1371/journal.pone.0110415

Calderwood, D. A., Fujioka, Y., de Pereda, J. M., García-Alvarez, B., Nakamoto, T., Margolis, B., et al. (2003). Integrin $\beta$ cytoplasmic domain interactions with phosphotyrosine-binding domains: a structural prototype for diversity in integrin signaling. Proc. Natl. Acad. Sci. U S A 100, 2272-2277. doi: 10. 1073/pnas.262791999 
Cariboni, A., Rakic, S., Liapi, A., Maggi, R., Goffinet, A., and Parnavelas, J. G. (2005). Reelin provides an inhibitory signal in the migration of gonadotropinreleasing hormone neurons. Development 132, 4709-4718. doi: 10.1242/dev. 02033

Castellano, E., Molina-Arcas, M., Krygowska, A. A., East, P., Warne, P., Nicol, A., et al. (2016). RAS signalling through PI3-Kinase controls cell migration via modulation of Reelin expression. Nat. Commun. 7:11245. doi: 10 . 1038/ncomms 11245

Catchpole, T., and Henkemeyer, M. (2011). EphB2 tyrosine kinase-dependent forward signaling in migration of neuronal progenitors that populate and form a distinct region of the dentate niche. J. Neurosci. 31, 11472-11483. doi: 10. 1523/JNEUROSCI.6349-10.2011

Chai, X., Förster, E., Zhao, S., Bock, H. H., and Frotscher, M. (2009). Reelin stabilizes the actin cytoskeleton of neuronal processes by inducing $\mathrm{n}$-cofilin phosphorylation at serine3. J. Neurosci. 29, 288-299. doi: 10.1523/JNEUROSCI. 2934-08.2009

Chai, X., Zhao, S., Fan, L., Zhang, W., Lu, X., Shao, H., et al. (2016). Reelin and cofilin cooperate during the migration of cortical neurons: a quantitative morphological analysis. Development 143, 1029-1040. doi: 10.1242/dev. 134163

Chen, Y., Beffert, U., Ertunc, M., Tang, T. S., Kavalali, E. T., Bezprozvanny, I., et al. (2005). Reelin modulates NMDA receptor activity in cortical neurons. J. Neurosci. 25, 8209-8216. doi: 10.1523/JNEUROSCI.1951-05.2005

Chen, Y., Durakoglugil, M. S., Xian, X., and Herz, J. (2010). ApoE4 reduces glutamate receptor function and synaptic plasticity by selectively impairing ApoE receptor recycling. Proc. Natl. Acad. Sci. US A 107, 12011-12016. doi: 10. 1073/pnas.0914984107

Chen, W. J., Goldstein, J. L., and Brown, M. S. (1990). NPXY, a sequence often found in cytoplasmic tails, is required for coated pit-mediated internalization of the low density lipoprotein receptor. J. Biol. Chem. 265, 3116-3123.

Chen, K., Ochalski, P. G., Tran, T. S., Sahir, N., Schubert, M., Pramatarova, A., et al. (2004). Interaction between Dabl and CrkII is promoted by Reelin signaling. J. Cell Sci. 117, 4527-4536. doi: 10.1242/jcs.01320

Cho, S. K., Choi, J. M., Kim, J. M., Cho, J. Y., Kim, S. S., Hong, S., et al. (2015). AKT-independent Reelin signaling requires interactions of heterotrimeric Go and Src. Biochem. Biophys. Res. Commun. 467, 1063-1069. doi: 10.1016/j.bbrc. 2015.09.167

Cissé, M., Halabisky, B., Harris, J., Devidze, N., Dubal, D. B., Sun, B., et al. (2011). Reversing EphB2 depletion rescues cognitive functions in Alzheimer model. Nature 469, 47-52. doi: 10.1038/nature09635

Cohen, J. C., and Hobbs, H. H. (2013). Genetics. Simple genetics for a complex disease. Science 340, 689-690. doi: 10.1126/science.1239101

Cole, A. R., Causeret, F., Yadirgi, G., Hastie, C. J., McLauchlan, H., McManus, E. J., et al. (2006). Distinct priming kinases contribute to differential regulation of collapsin response mediator proteins by glycogen synthase kinase-3 in vivo. J. Biol. Chem. 281, 16591-16598. doi: 10.1074/jbc.M513344200

Cooper, J. A., and Howell, B. W. (1999). Lipoprotein receptors: signaling functions in the brain? Cell 97, 671-674. doi: 10.1016/S0092-8674(00)80778-3

D'Arcangelo, G. (2005). The reeler mouse: anatomy of a mutant. Int. Rev. Neurobiol. 71, 383-417. doi: 10.1016/s0074-7742(05)71016-3

D’Arcangelo, G., Homayouni, R., Keshvara, L., Rice, D. S., Sheldon, M., and Curran, T. (1999). Reelin is a ligand for lipoprotein receptors. Neuron 24, 471-479. doi: 10.1016/s0896-6273(00)80860-0

D’Arcangelo, G., Miao, G. G., Chen, S. C., Soares, H. D., Morgan, J. I., and Curran, T. (1995). A protein related to extracellular matrix proteins deleted in the mouse mutant reeler. Nature 374, 719-723. doi: 10.1038/374719a0

de Bergeyck, V., Nakajima, K., Lambert de Rouvroit, C., Naerhuyzen, B., Goffinet, A. M., Miyata, T., et al. (1997). A truncated Reelin protein is produced but not secreted in the 'Orleans' reeler mutation (Reln[rl-Orl]). Brain Res. Mol. Brain Res. 50, 85-90. doi: 10.1016/s0169-328x(97)00166-6

Deyts, C., Thinakaran, G., and Parent, A. T. (2016). APP receptor? to be or not to be. Trends Pharmacol. Sci. 37, 390-411. doi: 10.1016/j.tips.2016.01.005

Dhavan, R., and Tsai, L. H. (2001). A decade of CDK5. Nat. Rev. Mol. Cell Biol. 2, 749-759. doi: 10.1038/35096019

DiBattista, A. M., Dumanis, S. B., Song, J. M., Bu, G., Weeber, E., Rebeck, G. W., et al. (2015). Very low density lipoprotein receptor regulates dendritic spine formation in a RasGRF1/CaMKII dependent manner. Biochim. Biophys. Acta 1853, 904-917. doi: 10.1016/j.bbamcr.2015.01.015
Dimou, L., and Götz, M. (2014). Glial cells as progenitors and stem cells: new roles in the healthy and diseased brain. Physiol. Rev. 94, 709-737. doi: 10. 1152/physrev.00036.2013

Ding, Y., Huang, L., Xian, X., Yuhanna, I. S., Wasser, C. R., Frotscher, M., et al. (2016). Loss of Reelin protects against atherosclerosis by reducing leukocyteendothelial cell adhesion and lesion macrophage accumulation. Sci. Signal. 9:ra29. doi: 10.1126/scisignal.aad5578

Divekar, S. D., Burrell, T. C., Lee, J. E., Weeber, E. J., and Rebeck, G. W. (2014). Ligand-induced homotypic and heterotypic clustering of apolipoprotein E receptor 2. J. Biol. Chem. 289, 15894-15903. doi: 10.1074/jbc.M113. 537548

Dohi, O., Takada, H., Wakabayashi, N., Yasui, K., Sakakura, C., Mitsufuji, S., et al. (2010). Epigenetic silencing of RELN in gastric cancer. Int. J. Oncol. 36, 85-92. doi: 10.3892/ijo_00000478

Dong, E., Caruncho, H., Liu, W. S., Smalheiser, N. R., Grayson, D. R., Costa, E., et al. (2003). A reelin-integrin receptor interaction regulates Arc mRNA translation in synaptoneurosomes. Proc. Natl. Acad. Sci. U S A 100, 5479-5484. doi: 10.1073/pnas.1031602100

Drakew, A., Frotscher, M., Deller, T., Ogawa, M., and Heimrich, B. (1998). Developmental distribution of a reeler gene-related antigen in the rat hippocampal formation visualized by CR-50 immunocytochemistry. Neuroscience 82, 1079-1086. doi: 10.1016/s0306-4522(97) 00326-6

Duit, S., Mayer, H., Blake, S. M., Schneider, W. J., and Nimpf, J. (2010). Differential functions of ApoER2 and very low density lipoprotein receptor in Reelin signaling depend on differential sorting of the receptors. J. Biol. Chem. 285, 4896-4908. doi: 10.1074/jbc.M109.025973

Dulabon, L., Olson, E. C., Taglienti, M. G., Eisenhuth, S., McGrath, B., Walsh, C. A., et al. (2000). Reelin binds $\alpha 3 \beta 1$ integrin and inhibits neuronal migration. Neuron 27, 33-44. doi: 10.1016/s0896-6273(00)00007-6

Durakoglugil, M. S., Chen, Y., White, C. L., Kavalali, E. T., and Herz, J. (2009). Reelin signaling antagonizes beta-amyloid at the synapse. Proc. Natl. Acad. Sci. U S A 106, 15938-15943. doi: 10.1073/pnas.0908176106

Falconer, D. S. (1951). Two new mutants, 'trembler' and 'reeler', with neurological actions in the house mouse (Mus musculus L.). J. Genet. 50, 192-201. doi: 10. 1007/bf02996215

Fatemi, S. H. (2001). Reelin mutations in mouse and man: from reeler mouse to schizophrenia, mood disorders, autism and lissencephaly. Mol. Psychiatry 6, 129-133. doi: 10.1038/sj.mp.4000129

Feng, L., Allen, N. S., Simo, S., and Cooper, J. A. (2007). Cullin 5 regulates Dab1 protein levels and neuron positioning during cortical development. Genes Dev. 21, 2717-2730. doi: 10.1101/gad.1604207

Feng, L., and Cooper, J. A. (2009). Dual functions of Dab1 during brain development. Mol. Cell. Biol. 29, 324-332. doi: 10.1128/MCB.00663-08

Folsom, T. D., and Fatemi, S. H. (2013). The involvement of Reelin in neurodevelopmental disorders. Neuropharmacology 68, 122-135. doi: 10 1016/j.neuropharm.2012.08.015

Forster, E., Bock, H. H., Herz, J., Chai, X., Frotscher, M., and Zhao, S. (2010). Emerging topics in Reelin function. Eur. J. Neurosci. 31, 1511-1518. doi: 10. 1111/j.1460-9568.2010.07222.x

Forster, E., Tielsch, A., Saum, B., Weiss, K. H., Johanssen, C., Graus-Porta, D., et al. (2002). Reelin, Disabled 1 and beta 1 integrins are required for the formation of the radial glial scaffold in the hippocampus. Proc. Natl. Acad. Sci. U S A 99, 13178-13183. doi: 10.1073/pnas.202035899

Franco, S. J., Martinez-Garay, I., Gil-Sanz, C., Harkins-Perry, S. R., and Müller, U. (2011). Reelin regulates cadherin function via Dab1/Rap1 to control neuronal migration and lamination in the neocortex. Neuron 69, 482-497. doi: 10.1016/j. neuron.2011.01.003

Fuchigami, T., Sato, Y., Tomita, Y., Takano, T., Miyauchi, S. Y., Tsuchiya, Y., et al. (2013). Dab1-mediated colocalization of multi-adaptor protein CIN85 with Reelin receptors, ApoER2 and VLDLR, in neurons. Genes Cells 18, 410-424. doi: $10.1111 /$ gtc. 12045

Gaiano, N., Nye, J. S., and Fishell, G. (2000). Radial glial identity is promoted by Notch1 signaling in the murine forebrain. Neuron 26, 395-404. doi: 10 . 1016/s0896-6273(00)81172-1

Gan, Z. R., Gould, R. J., Jacobs, J. W., Friedman, P. A., and Polokoff, M. A. (1988). Echistatin. A potent platelet aggregation inhibitor from the venom of the viper, Echis carinatus. J. Biol. Chem. 263, 19827-19832. 
Gao, Z., and Godbout, R. (2013). Reelin-Disabled-1 signaling in neuronal migration: splicing takes the stage. Cell. Mol. Life Sci. 70, 2319-2329. doi: 10. 1007/s00018-012-1171-6

García-Miranda, P., Peral, M. J., and Ilundain, A. A. (2010). Rat small intestine expresses the reelin-Disabled-1 signalling pathway. Exp. Physiol. 95, 498-507. doi: 10.1113/expphysiol.2009.050682

Gavín, R., Ureña, J., Rangel, A., Pastrana, M. A., Requena, J. R., Soriano, E., et al. (2008). Fibrillar prion peptide $\operatorname{PrP}(106-126)$ treatment induces Dab1 phosphorylation and impairs APP processing and Abeta production in cortical neurons. Neurobiol. Dis. 30, 243-254. doi: 10.1016/j.nbd.2008.02.001

Gelkop, S., Babichev, Y., and Isakov, N. (2001). T cell activation induces direct binding of the Crk adapter protein to the regulatory subunit of phosphatidylinositol 3-kinase (p85) via a complex mechanism involving the Cbl protein. J. Biol. Chem. 276, 36174-36182. doi: 10.1074/jbc.M100731200

Gilmore, E. C., Ohshima, T., Goffinet, A. M., Kulkarni, A. B., and Herrup, K. (1998). Cyclin-dependent kinase 5-deficient mice demonstrate novel developmental arrest in cerebral cortex. J. Neurosci. 18, 6370-6377.

Gil-Sanz, C., Franco, S. J., Martinez-Garay, I., Espinosa, A., Harkins-Perry, S., and Muller, U. (2013). Cajal-Retzius cells instruct neuronal migration by coincidence signaling between secreted and contact-dependent guidance cues. Neuron 79, 461-477. doi: 10.1016/j.neuron.2013.06.040

Giniger, E. (1998). A role for Abl in Notch signaling. Neuron 20, 667-681. doi: 10. 1016/s0896-6273(00)81007-7

Gong, C., Wang, T. W., Huang, H. S., and Parent, J. M. (2007). Reelin regulates neuronal progenitor migration in intact and epileptic hippocampus. J. Neurosci. 27, 1803-1811. doi: 10.1523/JNEUROSCI.3111-06.2007

Gotoh, T., Hattori, S., Nakamura, S., Kitayama, H., Noda, M., Takai, Y., et al. (1995). Identification of Rap1 as a target for the Crk SH3 domain-binding guanine nucleotide-releasing factor C3G. Mol. Cell. Biol. 15, 6746-6753. doi: 10. $1128 / \mathrm{mcb} .15 .12 .6746$

Gotthardt, M., Trommsdorff, M., Nevitt, M. F., Shelton, J., Richardson, J. A., Stockinger, W., et al. (2000). Interactions of the low density lipoprotein receptor gene family with cytosolic adaptor and scaffold proteins suggest diverse biological functions in cellular communication and signal transduction. J. Biol. Chem. 275, 25616-25624. doi: 10.1074/jbc.M000955200

Graus-Porta, D., Blaess, S., Senften, M., Littlewood-Evans, A., Damsky, C., Huang, Z., et al. (2001). $\beta 1$-class integrins regulate the development of laminae and folia in the cerebral and cerebellar cortex. Neuron 31, 367-379. doi: 10.1016/s08966273(01)00374-9

Groc, L., Choquet, D., Stephenson, F. A., Verrier, D., Manzoni, O. J., and Chavis, P. (2007). NMDA receptor surface trafficking and synaptic subunit composition are developmentally regulated by the extracellular matrix protein Reelin. J. Neurosci. 27, 10165-10175. doi: 10.1523/jneurosci.1772-07.2007

Guidotti, A., Auta, J., Davis, J. M., Di-Giorgi-Gerevini, V., Dwivedi, Y., Grayson, D. R., et al. (2000). Decrease in reelin and glutamic acid decarboxylase67 (GAD67) expression in schizophrenia and bipolar disorder: a postmortem brain study. Arch. Gen. Psychiatry 57, 1061-1069. doi: 10.1001/archpsyc.57.11. 1061

Haas, C. A., Dudeck, O., Kirsch, M., Huszka, C., Kann, G., Pollak, S., et al. (2002). Role for reelin in the development of granule cell dispersion in temporal lobe epilepsy. J. Neurosci. 22, 5797-5802.

Haass, C., and De Strooper, B. (1999). The presenilins in Alzheimer's disease-proteolysis holds the key. Science 286, 916-919. doi: 10.1126/science. 286.5441.916

Haass, C., Kaether, C., Thinakaran, G., and Sisodia, S. (2012). Trafficking and proteolytic processing of APP. Cold Spring Harb. Perspect. Med. 2:a006270. doi: 10.1101/cshperspect.a006270

Hack, I., Bancila, M., Loulier, K., Carroll, P., and Cremer, H. (2002). Reelin is a detachment signal in tangential chain-migration during postnatal neurogenesis. Nat. Neurosci. 5, 939-945. doi: 10.1038/nn923

Hack, I., Hellwig, S., Junghans, D., Brunne, B., Bock, H. H., Zhao, S., et al. (2007). Divergent roles of ApoER2 and Vldlr in the migration of cortical neurons. Development 134, 3883-3891. doi: 10.1242/dev.005447

Hartfuss, E., Forster, E., Bock, H. H., Hack, M. A., Leprince, P., Luque, J. M., et al. (2003). Reelin signaling directly affects radial glia morphology and biochemical maturation. Development 130, 4597-4609. doi: 10.1242/dev.00654

Hashimoto-Torii, K., Torii, M., Sarkisian, M. R., Bartley, C. M., Shen, J., Radtke, F., et al. (2008). Interaction between reelin and notch signaling regulates neuronal migration in the cerebral cortex. Neuron 60, 273-284. doi: 10.1016/j.neuron. 2008.09.026

Hatten, M. E., and Heintz, N. (2005). Large-scale genomic approaches to brain development and circuitry. Annu. Rev. Neurosci. 28, 89-108. doi: 10. 1146/annurev.neuro.26.041002.131436

He, X., Cooley, K., Chung, C. H., Dashti, N., and Tang, J. (2007). Apolipoprotein receptor 2 and X11 $\alpha / \beta$ mediate apolipoprotein E-induced endocytosis of amyloid-beta precursor protein and beta-secretase, leading to amyloid-beta production. J. Neurosci. 27, 4052-4060. doi: 10.1523/jneurosci.3993-06.2007

Hellwig, S., Hack, I., Kowalski, J., Brunne, B., Jarowyj, J., Unger, A., et al. (2011). Role for Reelin in neurotransmitter release. J. Neurosci. 31, 2352-2360. doi: 10. 1523/JNEUROSCI.3984-10.2011

Hellwig, S., Hack, I., Zucker, B., Brunne, B., and Junghans, D. (2012). Reelin together with ApoER2 regulates interneuron migration in the olfactory bulb. PLoS One 7:e50646. doi: 10.1371/journal.pone.0050646

Herrick, T. M., and Cooper, J. A. (2002). A hypomorphic allele of dab1 reveals regional differences in reelin-Dab1 signaling during brain development. Development 129, 787-796.

Herz, J. (2001). Lipoprotein receptors: beacons to neurons? Trends Neurosci. 24, 193-195. doi: 10.1016/s0166-2236(00)01768-9

Herz, J., and Bock, H. H. (2002). Lipoprotein receptors in the nervous system. Annu. Rev. Biochem. 71, 405-434. doi: 10.1146/annurev.biochem.71.110601. 135342

Herz, J., and Chen, Y. (2006). Reelin, lipoprotein receptors and synaptic plasticity. Nat. Rev. Neurosci. 7, 850-859. doi: 10.1038/nrn2009

Herz, J., Goldstein, J. L., Strickland, D. K., Ho, Y. K., and Brown, M. S. (1991). $39-\mathrm{kDa}$ protein modulates binding of ligands to low density lipoprotein receptor-related protein $/ \alpha 2$-macroglobulin receptor. J. Biol. Chem. 266, 21232-21238.

Herz, J., Hamann, U., Rogne, S., Myklebost, O., Gausepohl, H., and Stanley, K. K. (1988). Surface location and high affinity for calcium of a 500-kd liver membrane protein closely related to the LDL-receptor suggest a physiological role as lipoprotein receptor. EMBO J. 7, 4119-4127.

Herz, J., and Willnow, T. E. (1994). Functions of the LDL receptor gene family. Ann. N Y Acad. Sci. 737, 14-19. doi: 10.1111/j.1749-6632.1994.tb44298.x

Hiesberger, T., Trommsdorff, M., Howell, B. W., Goffinet, A., Mumby, M. C., Cooper, J. A., et al. (1999). Direct binding of Reelin to VLDL receptor and ApoE receptor 2 induces tyrosine phosphorylation of disabled-1 and modulates tau phosphorylation. Neuron 24, 481-489. doi: 10.1016/s0896-6273(00)80861-2

Hirota, Y., Kubo, K., Katayama, K., Honda, T., Fujino, T., Yamamoto, T. T., et al. (2015). Reelin receptors ApoER2 and VLDLR are expressed in distinct spatiotemporal patterns in developing mouse cerebral cortex. J. Comp. Neurol. 523, 463-478. doi: 10.1002/cne.23691

Hirotsune, S., Takahara, T., Sasaki, N., Hirose, K., Yoshiki, A., Ohashi, T., et al. (1995). The reeler gene encodes a protein with an EGF-like motif expressed by pioneer neurons. Nat. Genet. 10, 77-83. doi: 10.1038/ng0595-77

Ho, A., and Sudhof, T. C. (2004). Binding of F-spondin to amyloid-beta precursor protein: a candidate amyloid-beta precursor protein ligand that modulates amyloid-beta precursor protein cleavage. Proc. Natl. Acad. Sci. U S A 101, 2548-2553. doi: 10.1073/pnas.0308655100

Hoareau, C., Borrell, V., Soriano, E., Krebs, M. O., Prochiantz, A., and Allinquant, B. (2008). Amyloid precursor protein cytoplasmic domain antagonizes reelin neurite outgrowth inhibition of hippocampal neurons. Neurobiol. Aging 29, 542-553. doi: 10.1016/j.neurobiolaging.2006.11.012

Hoe, H. S., Lee, K. J., Carney, R. S., Lee, J., Markova, A., Lee, J. Y., et al. (2009). Interaction of reelin with amyloid precursor protein promotes neurite outgrowth. J. Neurosci. 29, 7459-7473. doi: 10.1523/JNEUROSCI.4872-08.2009

Hoe, H. S., Minami, S. S., Makarova, A., Lee, J., Hyman, B. T., Matsuoka, Y., et al. (2008). Fyn modulation of Dab1 effects on amyloid precursor protein and ApoE receptor 2 processing. J. Biol. Chem. 283, 6288-6299. doi: 10.1074/jbc. M704140200

Hoe, H. S., Pocivavsek, A., Chakraborty, G., Fu, Z., Vicini, S., Ehlers, M. D., et al. (2006a). Apolipoprotein E receptor 2 interactions with the N-methyl-Daspartate receptor. J. Biol. Chem. 281, 3425-3431. doi: 10.1074/jbc.M509380200

Hoe, H. S., Tran, T. S., Matsuoka, Y., Howell, B. W., and Rebeck, G. W. (2006b). DAB1 and Reelin effects on amyloid precursor protein and ApoE receptor 2 trafficking and processing. J. Biol. Chem. 281, 35176-35185. doi: 10.1074/jbc. M602162200 
Hoe, H. S., and Rebeck, G. W. (2005). Regulation of ApoE receptor proteolysis by ligand binding. Brain Res. Mol. Brain Res. 137, 31-39. doi: 10.1016/j. molbrainres.2005.02.013

Hoe, H. S., and Rebeck, G. W. (2008). Regulated proteolysis of APP and ApoE receptors. Mol. Neurobiol. 37, 64-72. doi: 10.1007/s12035-008$8017-0$

Hoe, H. S., Wessner, D., Beffert, U., Becker, A. G., Matsuoka, Y., and Rebeck, G. W. (2005). F-spondin interaction with the apolipoprotein E receptor ApoEr2 affects processing of amyloid precursor protein. Mol. Cell. Biol. 25, 9259-9268. doi: $10.1128 / \mathrm{mcb} .25 .21 .9259-9268.2005$

Homayouni, R., Magdaleno, S., Keshvara, L., Rice, D. S., and Curran, T. (2003). Interaction of Disabled-1 and the GTPase activating protein Dab2IP in mouse brain. Brain Res. Mol. Brain Res. 115, 121-129. doi: 10.1016/s0169328x (03)00176-1

Honda, T., and Nakajima, K. (2006). Mouse Disabled1 (DAB1) is a nucleocytoplasmic shuttling protein. J. Biol. Chem. 281, 38951-38965. doi: 10.1074/jbc.M609061200

Honda, T., and Nakajima, K. (2016). Proper level of cytosolic disabled-1, which is regulated by dual nuclear translocation pathways, is important for cortical neuronal migration. Cereb. Cortex 26, 3219-3236. doi: 10.1093/cercor/ bhv162

Howell, B. W., Hawkes, R., Soriano, P., and Cooper, J. A. (1997). Neuronal position in the developing brain is regulated by mouse disabled-1. Nature 389, 733-737. doi: $10.1038 / 39607$

Howell, B. W., Herrick, T. M., and Cooper, J. A. (1999a). Reelin-induced tyrosine [corrected] phosphorylation of disabled 1 during neuronal positioning. Genes Dev. 13, 643-648. doi: 10.1101/gad.13.6.643

Howell, B. W., Lanier, L. M., Frank, R., Gertler, F. B., and Cooper, J. A. (1999b). The disabled 1 phosphotyrosine-binding domain binds to the internalization signals of transmembrane glycoproteins and to phospholipids. Mol. Cell. Biol. 19, 5179-5188. doi: 10.1128/mcb.19.7.5179

Howell, B. W., Herrick, T. M., Hildebrand, J. D., Zhang, Y., and Cooper, J. A. (2000). Dab1 tyrosine phosphorylation sites relay positional signals during mouse brain development. Curr. Biol. 10, 877-885. doi: 10.1016/s09609822(00)00608-4

Howell, B. W., and Herz, J. (2001). The LDL receptor gene family: signaling functions during development. Curr. Opin. Neurobiol. 11, 74-81. doi: 10. 1016/s0959-4388(00)00176-8

Howell, K. R., Hoda, M. N., and Pillai, A. (2013). VEGF activates NR2B phosphorylation through Dab1 pathway. Neurosci. Lett. 552, 30-34. doi: 10. 1016/j.neulet.2013.07.032

Huang, Y., Magdaleno, S., Hopkins, R., Slaughter, C., Curran, T., and Keshvara, L. (2004). Tyrosine phosphorylated Disabled 1 recruits Crk family adapter proteins. Biochem. Biophys. Res. Commun. 318, 204-212. doi: 10.1016/j.bbrc. 2004.04.023

Huang, Y., Shah, V., Liu, T., and Keshvara, L. (2005). Signaling through Disabled 1 requires phosphoinositide binding. Biochem. Biophys. Res. Commun. 331, 1460-1468. doi: 10.1016/j.bbrc.2005.04.064

Hurtado-Chong, A., Yusta-Boyo, M. J., Vergaño-Vera, E., Bulfone, A., de Pablo, F., and Vicario-Abejón, C. (2009). IGF-I promotes neuronal migration and positioning in the olfactory bulb and the exit of neuroblasts from the subventricular zone. Eur. J. Neurosci. 30, 742-755. doi: 10.1111/j.1460-9568. 2009.06870.x

Hussain, M. M., Strickland, D. K., and Bakillah, A. (1999). The mammalian lowdensity lipoprotein receptor family. Annu. Rev. Nutr. 19, 141-172. doi: 10. 1146/annurev.nutr.19.1.141

Ikeda, Y., and Terashima, T. (1997). Expression of reelin, the gene responsible for the reeler mutation, in embryonic development and adulthood in the mouse. Dev. Dyn. 210, 157-172. doi: 10.1002/(SICI)10970177(199710)210:2<157::AID-AJA8 > 3.0.CO;2-F

Imai, H., Shoji, H., Ogata, M., Kagawa, Y., Owada, Y., Miyakawa, T., et al. (2016). Dorsal forebrain-specific deficiency of reelin-dab1 signal causes behavioral abnormalities related to psychiatric disorders. Cereb. Cortex 12:bhv334. doi: 10.1093/cercor/bhv334

Impagnatiello, F., Guidotti, A. R., Pesold, C., Dwivedi, Y., Caruncho, H., Pisu, M. G., et al. (1998). A decrease of reelin expression as a putative vulnerability factor in schizophrenia. Proc. Natl. Acad. Sci. U S A 95, 15718-15723. doi: 10. 1073/pnas.95.26.15718
Jossin, Y. (2011). Polarization of migrating cortical neurons by Rap1 and N-cadherin: revisiting the model for the reelin signaling pathway. Small GTPases 2, 322-328. doi: 10.4161/sgtp.18283

Jossin, Y., and Cooper, J. A. (2011). Reelin, Rap1 and N-cadherin orient the migration of multipolar neurons in the developing neocortex. Nat. Neurosci. 14, 697-703. doi: 10.1038/nn.2816

Jossin, Y., and Goffinet, A. M. (2007). Reelin signals through phosphatidylinositol 3-kinase and Akt to control cortical development and through mTor to regulate dendritic growth. Mol. Cell. Biol. 27, 7113-7124. doi: 10.1128/mcb.00928-07

Jossin, Y., Gui, L., and Goffinet, A. M. (2007). Processing of Reelin by embryonic neurons is important for function in tissue but not in dissociated cultured neurons. J. Neurosci. 27, 4243-4252. doi: 10.1523/JNEUROSCI.0023-07. 2007

Jossin, Y., Ignatova, N., Hiesberger, T., Herz, J., Lambert de Rouvroit, C., and Goffinet, A. M. (2004). The central fragment of Reelin, generated by proteolytic processing in vivo, is critical to its function during cortical plate development. J. Neurosci. 24, 514-521. doi: 10.1523/JNEUROSCI.3408-03.2004

Jung, P., Sato, T., Merlos-Suarez, A., Barriga, F. M., Iglesias, M., Rossell, D., et al. (2011). Isolation and in vitro expansion of human colonic stem cells. Nat. Med. 17, 1225-1227. doi: $10.1038 / \mathrm{nm} .2470$

Kawauchi, T. (2014). Cdk5 regulates multiple cellular events in neural development, function and disease. Dev. Growth Differ. 56, 335-348. doi: 10. 1111/dgd.12138

Kawauchi, T., Sekine, K., Shikanai, M., Chihama, K., Tomita, K., Kubo, K., et al. (2010). Rab GTPases-dependent endocytic pathways regulate neuronal migration and maturation through $\mathrm{N}$-cadherin trafficking. Neuron 67 , 588-602. doi: 10.1016/j.neuron.2010.07.007

Keilani, S., and Sugaya, K. (2008). Reelin induces a radial glial phenotype in human neural progenitor cells by activation of Notch-1. BMC Dev. Biol. 8:69. doi: 10 . 1186/1471-213X-8-69

Keshvara, L., Magdaleno, S., Benhayon, D., and Curran, T. (2002). Cyclindependent kinase 5 phosphorylates disabled 1 independently of Reelin signaling. J. Neurosci. 22, 4869-4877.

Kim, H. M., Qu, T., Kriho, V., Lacor, P., Smalheiser, N., Pappas, G. D., et al. (2002). Reelin function in neural stem cell biology. Proc. Natl. Acad. Sci. U S A 99, 4020-4025. doi: 10.1073/pnas.062698299

Klein, R. (2004). Eph/ephrin signaling in morphogenesis, neural development and plasticity. Curr. Opin. Cell Biol. 16, 580-589. doi: 10.1016/j.ceb.2004.07.002

Knuesel, I. (2010). Reelin-mediated signaling in neuropsychiatric and neurodegenerative diseases. Prog. Neurobiol. 91, 257-274. doi: 10.1016/j. pneurobio.2010.04.002

Knuesel, I., Nyffeler, M., Mormède, C., Muhia, M., Meyer, U., Pietropaolo, S., et al. (2009). Age-related accumulation of Reelin in amyloid-like deposits. Neurobiol. Aging 30, 697-716. doi: 10.1016/j.neurobiolaging.2007.08.011

Kobold, D., Grundmann, A., Piscaglia, F., Eisenbach, C., Neubauer, K., Steffgen, J., et al. (2002). Expression of reelin in hepatic stellate cells and during hepatic tissue repair: a novel marker for the differentiation of HSC from other liver myofibroblasts. J. Hepatol. 36, 607-613. doi: 10.1016/s0168-8278(02) 00050-8

Kocherhans, S., Madhusudan, A., Doehner, J., Breu, K. S., Nitsch, R. M., Fritschy, J. M., et al. (2010). Reduced Reelin expression accelerates amyloid-beta plaque formation and tau pathology in transgenic Alzheimer's disease mice. J. Neurosci. 30, 9228-9240. doi: 10.1523/JNEUROSCI.0418-10.2010

Kohno, T., Honda, T., Kubo, K., Nakano, Y., Tsuchiya, A., Murakami, T., et al. (2015). Importance of Reelin C-terminal region in the development and maintenance of the postnatal cerebral cortex and its regulation by specific proteolysis. J. Neurosci. 35, 4776-4787. doi: 10.1523/JNEUROSCI.4119-14. 2015

Kohno, S., Kohno, T., Nakano, Y., Suzuki, K., Ishii, M., Tagami, H., et al. (2009). Mechanism and significance of specific proteolytic cleavage of Reelin. Biochem. Biophys. Res. Commun. 380, 93-97. doi: 10.1016/j.bbrc.2009.01.039

Koie, M., Okumura, K., Hisanaga, A., Kamei, T., Sasaki, K., Deng, M., et al. (2014). Cleavage within Reelin repeat 3 regulates the duration and range of the signaling activity of Reelin protein. J. Biol. Chem. 289, 12922-12930. doi: 10. 1074/jbc.M113.536326

Krstic, D., Pfister, S., Notter, T., and Knuesel, I. (2013). Decisive role of Reelin signaling during early stages of Alzheimer's disease. Neuroscience 246, 108-116. doi: 10.1016/j.neuroscience.2013.04.042 
Krstic, D., Rodriguez, M., and Knuesel, I. (2012). Regulated proteolytic processing of Reelin through interplay of tissue plasminogen activator (tPA), ADAMTS-4, ADAMTS-5 and their modulators. PLoS One 7:e47793. doi: 10.1371/journal. pone. 0047793

Kubo, K., Mikoshiba, K., and Nakajima, K. (2002). Secreted Reelin molecules form homodimers. Neurosci. Res. 43, 381-388. doi: 10.1016/s0168-0102(02) 00068-8

Kuo, G., Arnaud, L., Kronstad-O’Brien, P., and Cooper, J. A. (2005). Absence of Fyn and Src causes a reeler-like phenotype. J. Neurosci. 25, 8578-8586. doi: 10. 1523/jneurosci.1656-05.2005

Kupferman, J. V., Basu, J., Russo, M. J., Guevarra, J., Cheung, S. K., and Siegelbaum, S. A. (2014). Reelin signaling specifies the molecular identity of the pyramidal neuron distal dendritic compartment. Cell 158, 1335-1347. doi: 10. 1016/j.cell.2014.07.035

Kurokawa, S., Bellinger, F. P., Hill, K. E., Burk, R. F., and Berry, M. J. (2014). Isoform-specific binding of selenoprotein $\mathrm{P}$ to the beta-propeller domain of apolipoprotein E receptor 2 mediates selenium supply. J. Biol. Chem. 289, 9195-9207. doi: 10.1074/jbc.m114.549014

Kwon, O. Y., Hwang, K., Kim, J. A., Kim, K., Kwon, I. C., Song, H. K., et al. (2010). Dab1 binds to Fe65 and diminishes the effect of Fe65 or LRP1 on APP processing. J. Cell. Biochem. 111, 508-519. doi: 10.1002/jcb.22738

Kysenius, K., Muggalla, P., Mätlik, K., Arumäe, U., and Huttunen, H. J. (2012). PCSK9 regulates neuronal apoptosis by adjusting ApoER2 levels and signaling. Cell. Mol. Life Sci. 69, 1903-1916. doi: 10.1007/s00018-012-0977-6

Lakomá, J., Garcia-Alonso, L., and Luque, J. M. (2011). Reelin sets the pace of neocortical neurogenesis. Development 138, 5223-5234. doi: 10.1242/dev. 063776

Lambert de Rouvroit, C., de Bergeyck, V., Cortvrindt, C., Bar, I., Eeckhout, Y., and Goffinet, A. M. (1999). Reelin, the extracellular matrix protein deficient in reeler mutant mice, is processed by a metalloproteinase. Exp. Neurol. 156, 214-217. doi: 10.1006/exnr.1998.7007

Lambert de Rouvroit, C., and Goffinet, A. M. (1998). The reeler mouse as a model of brain development. Adv. Anat. Embryol. Cell Biol. 150, 1-106. doi: 10. 1007/978-3-642-72257-8_1

Lane-Donovan, C., Philips, G. T., and Herz, J. (2014). More than cholesterol transporters: lipoprotein receptors in CNS function and neurodegeneration. Neuron 83, 771-787. doi: 10.1016/j.neuron.2014.08.005

Lane-Donovan, C., Philips, G. T., Wasser, C. R., Durakoglugil, M. S., Masiulis, I., Upadhaya, A., et al. (2015). Reelin protects against amyloid beta toxicity in vivo. Sci. Signal. 8:ra67. doi: 10.1126/scisignal.aaa6674

Larios, J. A., Jausoro, I., Benitez, M. L., Bronfman, F. C., and Marzolo, M. P. (2014). Neurotrophins regulate ApoER2 proteolysis through activation of the Trk signaling pathway. BMC Neurosci. 15:108. doi: 10.1186/1471-2202-15-108

Lawrenson, I. D., Krebs, D. L., Linossi, E. M., Zhang, J. G., McLennan, T. J., Collin, C., et al. (2015). Cortical layer inversion and deregulation of reelin signaling in the absence of SOCS6 and SOCS7. Cereb. Cortex doi: 10.1093/cercor/bhv253 [Epub ahead of print].

Lee, G. H., Chhangawala, Z., von Daake, S., Savas, J. N., Yates, J. R. III, Comoletti, D., et al. (2014). Reelin induces Erk1/2 signaling in cortical neurons through a non-canonical pathway. J. Biol. Chem. 289, 20307-20317. doi: 10.1074/jbc. M114.576249

Lee, G. H., Kim, S. H., Homayouni, R., and D’Arcangelo, G. (2012). Dab2ip regulates neuronal migration and neurite outgrowth in the developing neocortex. PLoS One 7:e46592. doi: 10.1371/journal.pone.0046592

Leeb, C., Eresheim, C., and Nimpf, J. (2014). Clusterin is a ligand for apolipoprotein E receptor 2 (ApoER2) and very low density lipoprotein receptor (VLDLR) and signals via the Reelin-signaling pathway. J. Biol. Chem. 289, 4161-4172. doi: 10.1074/jbc.M113.529271

Leemhuis, J., and Bock, H. H. (2011). Reelin modulates cytoskeletal organization by regulating Rho GTPases. Commun. Integr. Biol. 4, 254-257. doi: 10.4161/cib. 4.3.14890

Leemhuis, J., Bouché, E., Frotscher, M., Henle, F., Hein, L., Herz, J., et al. (2010). Reelin signals through apolipoprotein E receptor 2 and Cdc42 to increase growth cone motility and filopodia formation. J. Neurosci. 30, 14759-14772. doi: 10.1523/JNEUROSCI.4036-10.2010

Levenson, J. M., Qiu, S., and Weeber, E. J. (2008). The role of reelin in adult synaptic function and the genetic and epigenetic regulation of the reelin gene. Biochim. Biophys. Acta 1779, 422-431. doi: 10.1016/j.bbagrm.2008.01.001
Levy, A. D., Omar, M. H., and Koleske, A. J. (2014). Extracellular matrix control of dendritic spine and synapse structure and plasticity in adulthood. Front. Neuroanat. 8:116. doi: 10.3389/fnana.2014.00116

Li, T., Hawkes, C., Qureshi, H. Y., Kar, S., and Paudel, H. K. (2006). Cyclindependent protein kinase 5 primes microtubule-associated protein tau sitespecifically for glycogen synthase kinase $3 \alpha$. Biochemistry 45, 3134-3145. doi: $10.1021 / \mathrm{bi} 051635 \mathrm{j}$

Li, Y., Lu, W., Marzolo, M. P., and Bu, G. (2001). Differential functions of members of the low density lipoprotein receptor family suggested by their distinct endocytosis rates. J. Biol. Chem. 276, 18000-18006. doi: 10.1074/jbc. M101589200

Lin, L., Yan, F., Zhao, D., Lv, M., Liang, X., Dai, H., et al. (2016). Reelin promotes the adhesion and drug resistance of multiple myeloma cells via integrin $\beta 1$ signaling and STAT3. Oncotarget 7, 9844-9858. doi: 10.18632/oncotarget.7151

Lingwood, D., and Simons, K. (2010). Lipid rafts as a membrane-organizing principle. Science 327, 46-50. doi: 10.1126/science. 1174621

Litterst, C., Georgakopoulos, A., Shioi, J., Ghersi, E., Wisniewski, T., Wang, R., et al. (2007). Ligand binding and calcium influx induce distinct ectodomain/gamma-secretase-processing pathways of EphB2 receptor. J. Biol. Chem. 282, 16155-16163. doi: 10.1074/jbc.M611449200

Liu, M., Wu, G., Baysarowich, J., Kavana, M., Addona, G. H., Bierilo, K. K., et al. (2010). PCSK9 is not involved in the degradation of LDL receptors and BACE1 in the adult mouse brain. J. Lipid Res. 51, 2611-2618. doi: 10.1194/jlr.M006635

Lonze, B. E., and Ginty, D. D. (2002). Function and regulation of CREB family transcription factors in the nervous system. Neuron 35, 605-623. doi: 10 . 1016/s0896-6273(02)00828-0

Lugli, G., Krueger, J. M., Davis, J. M., Persico, A. M., Keller, F., and Smalheiser, N. R. (2003). Methodological factors influencing measurement and processing of plasma reelin in humans. BMC Biochem. 4:9. doi: 10.1186/1471-2091-4-9

Lutter, S., Xie, S., Tatin, F., and Makinen, T. (2012). Smooth muscle-endothelial cell communication activates Reelin signaling and regulates lymphatic vessel formation. J. Cell Biol. 197, 837-849. doi: 10.1083/jcb.201110132

Magdaleno, S. M., and Curran, T. (2001). Brain development: integrins and the Reelin pathway. Curr. Biol. 11, R1032-R1035. doi: 10.1016/s09609822(01)00618-2

Manoharan, M., Muhammad, S. A., and Sowdhamini, R. (2015). Sequence analysis and evolutionary studies of reelin proteins. Bioinform. Biol. Insights 9, 187-193. doi: $10.4137 /$ BBI.s26530

Masiulis, I., Quill, T. A., Burk, R. F., and Herz, J. (2009). Differential functions of the Apoer2 intracellular domain in selenium uptake and cell signaling. Biol. Chem. 390, 67-73. doi: 10.1515/BC.2009.011

Matsuki, T., Matthews, R. T., Cooper, J. A., van der Brug, M. P., Cookson, M. R., Hardy, J. A., et al. (2010). Reelin and stk25 have opposing roles in neuronal polarization and dendritic Golgi deployment. Cell 143, 826-836. doi: 10.1016/j. cell.2010.10.029

May, P., Bock, H. H., and Herz, J. (2003a). Integration of endocytosis and signal transduction by lipoprotein receptors. Sci. STKE 2003:PE12. doi: 10.1126/stke.2003.176.pe12

May, P., Bock, H. H., Nimpf, J., and Herz, J. (2003b). Differential glycosylation regulates processing of lipoprotein receptors by gamma-secretase. J. Biol. Chem. 278, 37386-37392. doi: 10.1074/jbc.m305858200

Mayer, H., Duit, S., Hauser, C., Schneider, W. J., and Nimpf, J. (2006). Reconstitution of the Reelin signaling pathway in fibroblasts demonstrates that Dab1 phosphorylation is independent of receptor localization in lipid rafts. Mol. Cell. Biol. 26, 19-27. doi: 10.1128/mcb.26.1.19-27.2006

Merrifield, C. J., and Kaksonen, M. (2014). Endocytic accessory factors and regulation of clathrin-mediated endocytosis. Cold Spring Harb. Perspect. Biol. 6:a016733. doi: 10.1101/cshperspect.a016733

Meseke, M., Rosenberger, G., and Forster, E. (2013). Reelin and the Cdc42/Rac1 guanine nucleotide exchange factor $\alpha$ PIX/Arhgef6 promote dendritic Golgi translocation in hippocampal neurons. Eur. J. Neurosci. 37, 1404-1412. doi: 10. 1111/ejn.12153

Miao, G. G., Smeyne, R. J., D’Arcangelo, G., Copeland, N. G., Jenkins, N. A., Morgan, J. I., et al. (1994). Isolation of an allele of reeler by insertional mutagenesis. Proc. Natl. Acad. Sci. U S A 91, 11050-11054. doi: 10.1073/pnas. 91.23.11050

Minami, S. S., Hoe, H. S., and Rebeck, G. W. (2011). Fyn kinase regulates the association between amyloid precursor protein and Dab1 by promoting their 
localization to detergent-resistant membranes. J. Neurochem. 118, 879-890. doi: 10.1111/j.1471-4159.2011.07296.x

Minami, S. S., Sung, Y. M., Dumanis, S. B., Chi, S. H., Burns, M. P., Ann, E. J., et al. (2010). The cytoplasmic adaptor protein X11alpha and extracellular matrix protein Reelin regulate ApoE receptor 2 trafficking and cell movement. FASEB J. 24, 58-69. doi: 10.1096/fj.09-138123

Moon, U. Y., Park, J. Y., Park, R., Cho, J. Y., Hughes, L. J., Mckenna, J., et al. (2015). Impaired reelin-Dab1 signaling contributes to neuronal migration deficits of tuberous sclerosis complex. Cell Rep. 12, 965-978. doi: 10.1016/j.celrep.2015. 07.013

Morimura, T., Hattori, M., Ogawa, M., and Mikoshiba, K. (2005). Disabled1 regulates the intracellular trafficking of reelin receptors. J. Biol. Chem. 280, 16901-16908. doi: 10.1074/jbc.m409048200

Müller, T., Meyer, H. E., Egensperger, R., and Marcus, K. (2008). The amyloid precursor protein intracellular domain (AICD) as modulator of gene expression, apoptosis and cytoskeletal dynamics-relevance for Alzheimer's disease. Prog. Neurobiol. 85, 393-406. doi: 10.1016/j.pneurobio.2008.05.002

Nolt, M. J., Lin, Y., Hruska, M., Murphy, J., Sheffler-Colins, S. I., Kayser, M. S., et al. (2011). EphB controls NMDA receptor function and synaptic targeting in a subunit-specific manner. J. Neurosci. 31, 5353-5364. doi: 10.1523/JNEUROSCI. 0282-11.2011

North, H. A., Clifford, M. A., and Donoghue, M. J. (2013). 'Til Eph do us part': intercellular signaling via Eph receptors and ephrin ligands guides cerebral cortical development from birth through maturation. Cereb. Cortex 23, 1765-1773. doi: 10.1093/cercor/bhs183

O'Brien, R. J., and Wong, P. C. (2011). Amyloid precursor protein processing and Alzheimer's disease. Annu. Rev. Neurosci. 34, 185-204. doi: 10.1146/annurevneuro-061010-113613

Ogden, K. K., Ozkan, E. D., and Rumbaugh, G. (2016). Prioritizing the development of mouse models for childhood brain disorders. Neuropharmacology 100, 2-16. doi: 10.1016/j.neuropharm.2015. 07.029

Ohshima, T. (2015). Neuronal migration and protein kinases. Front. Neurosci. 8:458. doi: $10.3389 /$ fnins. 2014.00458

Ohshima, T., Ogawa, M., Takeuchi, K., Takahashi, S., Kulkarni, A. B., and Mikoshiba, K. (2002). Cyclin-dependent kinase 5/p35 contributes synergistically with Reelin/Dabl to the positioning of facial branchiomotor and inferior olive neurons in the developing mouse hindbrain. J. Neurosci. 22, 4036-4044.

Ohshima, T., Suzuki, H., Morimura, T., Ogawa, M., and Mikoshiba, K. (2007). Modulation of Reelin signaling by Cyclin-dependent kinase 5. Brain Res. 1140, 84-95. doi: 10.1016/j.brainres.2006.01.121

Okamura, Y., Nomoto, S., Kanda, M., Hayashi, M., Nishikawa, Y., Fujii, T., et al. (2011). Reduced expression of reelin (RELN) gene is associated with high recurrence rate of hepatocellular carcinoma. Ann. Surg. Oncol. 18, 572-579. doi: 10.1245/s10434-010-1273-z

Olson, G. E., Winfrey, V. P., Nagdas, S. K., Hill, K. E., and Burk, R. F. (2007). Apolipoprotein E receptor-2 (ApoER2) mediates selenium uptake from selenoprotein P by the mouse testis. J. Biol. Chem. 282, 12290-12297. doi: 10. 1074/jbc.m611403200

Parisiadou, L., and Efthimiopoulos, S. (2007). Expression of mDab1 promotes the stability and processing of amyloid precursor protein and this effect is counteracted by X11 $\alpha$. Neurobiol. Aging 28, 377-388. doi: 10.1016/j. neurobiolaging.2005.12.015

Park, T. J., and Curran, T. (2008). Crk and Crk-like play essential overlapping roles downstream of disabled-1 in the Reelin pathway. J. Neurosci. 28, 13551-13562. doi: 10.1523/JNEUROSCI.4323-08.2008

Pasquale, E. B. (2008). Eph-ephrin bidirectional signaling in physiology and disease. Cell 131, 38-52. doi: 10.1016/j.cell.2008.03.011

Pasten, C., Cerda, J., Jausoro, I., Court, F. A., Caceres, A., and Marzolo, M. P. (2015). ApoER2 and Reelin are expressed in regenerating peripheral nerve and regulate Schwann cell migration by activating the Racl GEF protein, Tiam1. Mol. Cell. Neurosci. 69, 1-11. doi: 10.1016/j.mcn.2015.09.004

Perez-Garcia, C. G., Tissir, F., Goffinet, A. M., and Meyer, G. (2004). Reelin receptors in developing laminated brain structures of mouse and human. Eur. J. Neurosci. 20, 2827-2832. doi: 10.1111/j.1460-9568.2004.03733.x

Perrone, G., Vincenzi, B., Zagami, M., Santini, D., Panteri, R., Flammia, G., et al. (2007). Reelin expression in human prostate cancer: a marker of tumor aggressiveness based on correlation with grade. Mod. Pathol. 20, 344-351. doi: 10.1038/modpathol.3800743

Persico, A. M., D’Agruma, L., Maiorano, N., Totaro, A., Militerni, R., Bravaccio, C., et al. (2001). Reelin gene alleles and haplotypes as a factor predisposing to autistic disorder. Mol. Psychiatry 6, 150-159. doi: 10.1038/sj.mp.40 00850

Pesold, C., Impagnatiello, F., Pisu, M. G., Uzunov, D. P., Costa, E., Guidotti, A., et al. (1998). Reelin is preferentially expressed in neurons synthesizing gamma-aminobutyric acid in cortex and hippocampus of adult rats. Proc. Natl. Acad. Sci. U S A 95, 3221-3226. doi: 10.1073/pnas.95.6.3221

Peterziel, H., Sackmann, T., Strelau, J., Kuhn, P. H., Lichtenthaler, S. F., Marom, K., et al. (2011). F-spondin regulates neuronal survival through activation of disabled-1 in the chicken ciliary ganglion. Mol. Cell. Neurosci. 46, 483-497. doi: 10.1016/j.men.2010.12.001

Pierfelice, T., Alberi, L., and Gaiano, N. (2011). Notch in the vertebrate nervous system: an old dog with new tricks. Neuron 69, 840-855. doi: 10.1016/j.neuron. 2011.02.031

Plattner, F., Angelo, M., and Giese, K. P. (2006). The roles of cyclin-dependent kinase 5 and glycogen synthase kinase 3 in tau hyperphosphorylation. J. Biol. Chem. 281, 25457-25465. doi: 10.1074/jbc.m603469200

Pohlkamp, T., David, C., Cauli, B., Gallopin, T., Bouché, E., Karagiannis, A., et al. (2014). Characterization and distribution of Reelin-positive interneuron subtypes in the rat barrel cortex. Cereb. Cortex 24, 3046-3058. doi: 10. 1093/cercor/bht161

Poirier, S., Mayer, G., Benjannet, S., Bergeron, E., Marcinkiewicz, J., Nassoury, N., et al. (2008). The proprotein convertase PCSK9 induces the degradation of low density lipoprotein receptor (LDLR) and its closest family members VLDLR and ApoER2. J. Biol. Chem. 283, 2363-2372. doi: 10.1074/jbc.m7080 98200

Pramatarova, A., Chen, K., and Howell, B. W. (2008). A genetic interaction between the APP and Dab1 genes influences brain development. Mol. Cell. Neurosci. 37, 178-186. doi: 10.1016/j.mcn.2007.09.008

Pramatarova, A., Ochalski, P. G., Chen, K., Gropman, A., Myers, S., Min, K. T., et al. (2003). Nck $\beta 1$ interacts with tyrosine-phosphorylated disabled 1 and redistributes in Reelin-stimulated neurons. Mol. Cell. Biol. 23, 7210-7221. doi: $10.1128 / \mathrm{mcb} .23 .20 .7210-7221.2003$

Pujadas, L., Rossi, D., Andres, R., Teixeira, C. M., Serra-Vidal, B., Parcerisas, A., et al. (2014). Reelin delays amyloid-beta fibril formation and rescues cognitive deficits in a model of Alzheimer's disease. Nat. Commun. 5:3443. doi: 10. 1038/ncomms 4443

Qiao, S., and Homayouni, R. (2015). Dab2IP regulates neuronal positioning, Rap1 activity and integrin signaling in the developing cortex. Dev. Neurosci. 37, 131-141. doi: 10.1159/000369092

Radakovits, R., Barros, C. S., Belvindrah, R., Patton, B., and Muller, U. (2009). Regulation of radial glial survival by signals from the meninges. J. Neurosci. 29, 7694-7705. doi: 10.1523/JNEUROSCI.5537-08.2009

Ramos-Moreno, T., Galazo, M. J., Porrero, C., Martínez-Cerdeño, V., and Clascá, F. (2006). Extracellular matrix molecules and synaptic plasticity: immunomapping of intracellular and secreted Reelin in the adult rat brain. Eur. J. Neurosci. 23, 401-422. doi: 10.1111/j.1460-9568.2005.04567.x

Reddy, S. S., Connor, T. E., Weeber, E. J., and Rebeck, W. (2011). Similarities and differences in structure, expression and functions of VLDLR and ApoER2. Mol. Neurodegener. 6:30. doi: 10.1186/1750-1326-6-30

Rice, D. S., and Curran, T. (1999). Mutant mice with scrambled brains: understanding the signaling pathways that control cell positioning in the CNS. Genes Dev. 13, 2758-2773. doi: 10.1101/gad.13.21.2758

Rice, D. S., and Curran, T. (2001). Role of the reelin signaling pathway in central nervous system development. Annu. Rev. Neurosci. 24, 1005-1039. doi: 10. 1146/annurev.neuro.24.1.1005

Rice, D. S., Sheldon, M., D'Arcangelo, G., Nakajima, K., Goldowitz, D., and Curran, T. (1998). Disabled-1 acts downstream of Reelin in a signaling pathway that controls laminar organization in the mammalian brain. Development 125 , 3719-3729.

Rice, H. C., Young-Pearse, T. L., and Selkoe, D. J. (2013). Systematic evaluation of candidate ligands regulating ectodomain shedding of amyloid precursor protein. Biochemistry 52, 3264-3277. doi: 10.1021/bi400165f

Rogers, J. T., Rusiana, I., Trotter, J., Zhao, L., Donaldson, E., Pak, D. T., et al. (2011). Reelin supplementation enhances cognitive ability, synaptic plasticity 
and dendritic spine density. Learn. Mem. 18, 558-564. doi: 10.1101/lm. 2153511

Rogers, J. T., and Weeber, E. J. (2008). Reelin and ApoE actions on signal transduction, synaptic function and memory formation. Neuron Glia Biol. 4, 259-270. doi: 10.1017/S1740925X09990184

Rogers, J. T., Zhao, L., Trotter, J. H., Rusiana, I., Peters, M. M., Li, Q., et al. (2013). Reelin supplementation recovers sensorimotor gating, synaptic plasticity and associative learning deficits in the heterozygous reeler mouse. J. Psychopharmacol. 27, 386-395. doi: 10.1177/0269881112463468

Rossel, M., Loulier, K., Feuillet, C., Alonso, S., and Carroll, P. (2005). Reelin signaling is necessary for a specific step in the migration of hindbrain efferent neurons. Development 132, 1175-1185. doi: 10.1242/dev.01683

Rossman, K. L., Der, C. J., and Sondek, J. (2005). GEF means go: turning on RHO GTPases with guanine nucleotide-exchange factors. Nat. Rev. Mol. Cell Biol. 6, 167-180. doi: 10.1038/nrm1587

Ruoslahti, E. (1996). RGD and other recognition sequences for integrins. Annu. Rev. Cell Dev. Biol. 12, 697-715. doi: 10.1146/annurev.cellbio.12.1.697

Sáez-Valero, J., Costell, M., Sjögren, M., Andreasen, N., Blennow, K., and Luque, J. M. (2003). Altered levels of cerebrospinal fluid reelin in frontotemporal dementia and Alzheimer's disease. J. Neurosci. Res. 72, 132-136. doi: 10. 1002/jnr. 10554

Sanada, K., Gupta, A., and Tsai, L. H. (2004). Disabled-1-regulated adhesion of migrating neurons to radial glial fiber contributes to neuronal positioning during early corticogenesis. Neuron 42, 197-211. doi: 10.1016/s08966273(04)00222-3

Sato, N., Fukushima, N., Chang, R., Matsubayashi, H., and Goggins, M. (2006). Differential and epigenetic gene expression profiling identifies frequent disruption of the RELN pathway in pancreatic cancers. Gastroenterology 130, 548-565. doi: 10.1053/j.gastro.2005.11.008

Sato, Y., Kobayashi, D., Kohno, T., Kidani, Y., Prox, J., Becker-Pauly, C., et al. (2016). Determination of cleavage site of Reelin between its sixth and seventh repeat and contribution of meprin metalloproteases to the cleavage. J. Biochem. 159, 305-312. doi: 10.1093/jb/mvv102

Schmid, R. S., Jo, R., Shelton, S., Kreidberg, J. A., and Anton, E. S. (2005). Reelin, integrin and DAB1 interactions during embryonic cerebral cortical development. Cereb. Cortex 15, 1632-1636. doi: 10.1093/cercor/ bhi041

Schmid, R. S., Shelton, S., Stanco, A., Yokota, Y., Kreidberg, J. A., and Anton, E. S. (2004). $\alpha 3 \beta 1$ integrin modulates neuronal migration and placement during early stages of cerebral cortical development. Development 131, 6023-6031. doi: $10.1242 /$ dev. 01532

Sekine, K., Kawauchi, T., Kubo, K., Honda, T., Herz, J., Hattori, M., et al. (2012). Reelin controls neuronal positioning by promoting cell-matrix adhesion via inside-out activation of integrin $\alpha 5 \beta 1$. Neuron 76, 353-369. doi: 10.1016/j. neuron.2012.07.020

Selkoe, D. J. (2000). Toward a comprehensive theory for Alzheimer's disease. hypothesis: Alzheimer's disease is caused by the cerebral accumulation and cytotoxicity of amyloid beta-protein. Ann. N Y Acad. Sci. 924, 17-25. doi: 10. $1111 / j .1749-6632.2000 . t b 05554 . x$

Selkoe, D. J. (2008). Soluble oligomers of the amyloid beta-protein impair synaptic plasticity and behavior. Behav. Brain Res. 192, 106-113. doi: 10.1016/j.bbr.2008. 02.016

Sengupta, A., Wu, Q., Grundke-Iqbal, I., Iqbal, K., and Singh, T. J. (1997). Potentiation of GSK-3-catalyzed Alzheimer-like phosphorylation of human tau by cdk5. Mol. Cell. Biochem. 167, 99-105. doi: 10.1023/A:1006883 924775

Sentürk, A., Pfennig, S., Weiss, A., Burk, K., and Acker-Palmer, A. (2011). Ephrin Bs are essential components of the Reelin pathway to regulate neuronal migration. Nature 472, 356-360. doi: 10.1038/nature09874

Senzaki, K., Ogawa, M., and Yagi, T. (1999). Proteins of the CNR family are multiple receptors for Reelin. Cell 99, 635-647. doi: 10.1016/s00928674(00)81552-4

Shah, K., and Lahiri, D. K. (2014). Cdk5 activity in the brain-multiple paths of regulation. J. Cell Sci. 127, 2391-2400. doi: 10.1242/jcs. 147553

Shah, B., Lutter, D., Tsytsyura, Y., Glyvuk, N., Sakakibara, A., Klingauf, J., et al. (2016). Rap1 GTPases are master regulators of neural cell polarity in the developing neocortex. Cereb. Cortex. doi: 10.1093/cercor/bhv341 [Epub ahead of print].
Sheldon, M., Rice, D. S., D’Arcangelo, G., Yoneshima, H., Nakajima, K., Mikoshiba, K., et al. (1997). Scrambler and yotari disrupt the disabled gene and produce a reeler-like phenotype in mice. Nature 389, 730-733. doi: 10. $1038 / 39601$

Shepherd, J. D., and Bear, M. F. (2011). New views of Arc, a master regulator of synaptic plasticity. Nat. Neurosci. 14, 279-284. doi: 10.1038/nn.2708

Sibbe, M., Förster, E., Basak, O., Taylor, V., and Frotscher, M. (2009). Reelin and Notch1 cooperate in the development of the dentate gyrus. J. Neurosci. 29, 8578-8585. doi: 10.1523/JNEUROSCI.0958-09.2009

Simó, S., and Cooper, J. A. (2013). Rbx2 regulates neuronal migration through different cullin 5-RING ligase adaptors. Dev. Cell 27, 399-411. doi: 10.1016/j. devcel.2013.09.022

Simó, S., Jossin, Y., and Cooper, J. A. (2010). Cullin 5 regulates cortical layering by modulating the speed and duration of Dab1-dependent neuronal migration. J. Neurosci. 30, 5668-5676. doi: 10.1523/JNEUROSCI.0035-10.2010

Simó, S., Pujadas, L., Segura, M. F., La Torre, A., Del Rio, J. A., Urena, J. M., et al. (2007). Reelin induces the detachment of postnatal subventricular zone cells and the expression of the Egr-1 through Erk1/2 activation. Cereb. Cortex 17, 294-303. doi: 10.1093/cercor/bhj147

Sinha, R. K., Yang, X. V., Fernández, J. A., Xu, X., Mosnier, L. O., and Griffin, J. H. (2016). Apolipoprotein E receptor 2 mediates activated protein C-induced endothelial Akt activation and endothelial barrier stabilization. Arterioscler. Thromb. Vasc. Biol. 36, 518-524. doi: 10.1161/atvbaha.115.306795

Smalheiser, N. R., Costa, E., Guidotti, A., Impagnatiello, F., Auta, J., Lacor, P., et al. (2000). Expression of reelin in adult mammalian blood, liver, pituitary pars intermedia and adrenal chromaffin cells. Proc. Natl. Acad. Sci. U S A 97, 1281-1286. doi: 10.1073/pnas.97.3.1281

Sotelo, P., Farfán, P., Benitez, M. L., Bu, G., and Marzolo, M. P. (2014). Sorting nexin 17 regulates ApoER2 recycling and reelin signaling. PLoS One 9:e93672. doi: 10.1371/journal.pone.0093672

Stein, T., Cosimo, E., Yu, X., Smith, P. R., Simon, R., Cottrell, L., et al. (2010). Loss of reelin expression in breast cancer is epigenetically controlled and associated with poor prognosis. Am. J. Pathol. 177, 2323-2333. doi: 10.2353/ajpath.2010. 100209

Stockinger, W., Brandes, C., Fasching, D., Hermann, M., Gotthardt, M., Herz, J., et al. (2000). The reelin receptor ApoER2 recruits JNK-interacting proteins-1 and -2. J. Biol. Chem. 275, 25625-25632. doi: 10.1074/jbc.m0041 19200

Stockinger, W., Sailler, B., Strasser, V., Recheis, B., Fasching, D., Kahr, L., et al. (2002). The PX-domain protein SNX17 interacts with members of the LDL receptor family and modulates endocytosis of the LDL receptor. EMBO J. 21, 4259-4267. doi: 10.1093/emboj/cdf435

Stolt, P. C., and Bock, H. H. (2006). Modulation of lipoprotein receptor functions by intracellular adaptor proteins. Cell. Signal. 18, 1560-1571. doi: 10.1016/j. cellsig.2006.03.008

Stolt, P. C., Chen, Y., Liu, P., Bock, H. H., Blacklow, S. C., and Herz, J. (2005). Phosphoinositide binding by the disabled-1 PTB domain is necessary for membrane localization and Reelin signal transduction. J. Biol. Chem. 280, 9671-9677. doi: 10.1074/jbc.m413356200

Stolt, P. C., Jeon, H., Song, H. K., Herz, J., Eck, M. J., and Blacklow, S. C. (2003). Origins of peptide selectivity and phosphoinositide binding revealed by structures of disabled-1 PTB domain complexes. Structure 11, 569-579. doi: 10 . 1016/s0969-2126(03)00068-6

Strasser, V., Fasching, D., Hauser, C., Mayer, H., Bock, H. H., Hiesberger, T., et al. (2004). Receptor clustering is involved in Reelin signaling. Mol. Cell. Biol. 24, 1378-1386. doi: 10.1128/mcb.24.3.1378-1386.2004

Strittmatter, W. J., Saunders, A. M., Schmechel, D., Pericak-Vance, M., Enghild, J., Salvesen, G. S., et al. (1993). Apolipoprotein E: high-avidity binding to beta-amyloid and increased frequency of type 4 allele in late-onset familial Alzheimer disease. Proc. Natl. Acad. Sci. U S A 90, 1977-1981. doi: 10. 1073/pnas.90.5.1977

Sun, X. M., and Soutar, A. K. (2003). The transmembrane domain and PXXP motifs of ApoE receptor 2 exclude it from carrying out clathrin-mediated endocytosis. J. Biol. Chem. 278, 19926-19932. doi: 10.1074/jbc.m302047200

Sweet, H. O., Bronson, R. T., Johnson, K. R., Cook, S. A., and Davisson, M. T. (1996). Scrambler, a new neurological mutation of the mouse with abnormalities of neuronal migration. Mamm. Genome 7, 798-802. doi: 10. $1007 / 8003359900240$ 
Telese, F., Ma, Q., Perez, P. M., Notani, D., Oh, S., Li, W., et al. (2015). LRP8reelin-regulated neuronal enhancer signature underlying learning and memory formation. Neuron 86, 696-710. doi: 10.1016/j.neuron.2015.03.033

Tinnes, S., Ringwald, J., and Haas, C. A. (2013). TIMP-1 inhibits the proteolytic processing of Reelin in experimental epilepsy. FASEB J. 27, 2542-2552. doi: 10. 1096/fj.12-224899

Tissir, F., and Goffinet, A. M. (2003). Reelin and brain development. Nat. Rev. Neurosci. 4, 496-505. doi: 10.1038/nrn1113

Trommsdorff, M., Borg, J. P., Margolis, B., and Herz, J. (1998). Interaction of cytosolic adaptor proteins with neuronal apolipoprotein E receptors and the amyloid precursor protein. J. Biol. Chem. 273, 33556-33560. doi: 10.1074/jbc. 273.50.33556

Trommsdorff, M., Gotthardt, M., Hiesberger, T., Shelton, J., Stockinger, W., Nimpf, J., et al. (1999). Reeler/disabled-like disruption of neuronal migration in knockout mice lacking the VLDL receptor and ApoE receptor 2. Cell 97, 689-701. doi: 10.1016/s0092-8674(00)80782-5

Trotter, J., Lee, G. H., Kazdoba, T. M., Crowell, B., Domogauer, J., Mahoney, H. M., et al. (2013). Dab1 is required for synaptic plasticity and associative learning. J. Neurosci. 33, 15652-15668. doi: 10.1523/JNEUROSCI.2010-13.2013

Trotter, J. H., Lussier, A. L., Psilos, K. E., Mahoney, H. L., Sponaugle, A. E., Hoe, H. S., et al. (2014). Extracellular proteolysis of reelin by tissue plasminogen activator following synaptic potentiation. Neuroscience 274, 299-307. doi: 10 . 1016/j.neuroscience.2014.05.046

Tseng, W. L., Chen, T. H., Huang, C. C., Huang, Y. H., Yeh, C. F., Tsai, H. J., et al. (2014). Impaired thrombin generation in Reelin-deficient mice: a potential role of plasma Reelin in hemostasis. J. Thromb. Haemost. 12, 2054-2064. doi: 10. $1111 /$ jth.12736

Uchida, Y., Ohshima, T., Sasaki, Y., Suzuki, H., Yanai, S., Yamashita, N., et al. (2005). Semaphorin3A signalling is mediated via sequential Cdk5 and GSK3beta phosphorylation of CRMP2: implication of common phosphorylating mechanism underlying axon guidance and Alzheimer's disease. Genes Cells 10, 165-179. doi: 10.1111/j.1365-2443.2005.00827.x

Underhill, G. H., George, D., Bremer, E. G., and Kansas, G. S. (2003). Gene expression profiling reveals a highly specialized genetic program of plasma cells. Blood 101, 4013-4021. doi: 10.1182/blood-2002-08-2673

Utsunomiya-Tate, N., Kubo, K., Tate, S., Kainosho, M., Katayama, E., Nakajima, K., et al. (2000). Reelin molecules assemble together to form a large protein complex, which is inhibited by the function-blocking CR-50 antibody. Proc. Natl. Acad. Sci. U S A 97, 9729-9734. doi: 10.1073/pnas.160 272497

Verhey, K. J., Meyer, D., Deehan, R., Blenis, J., Schnapp, B. J., Rapoport, T. A., et al. (2001). Cargo of kinesin identified as JIP scaffolding proteins and associated signaling molecules. J. Cell Biol. 152, 959-970. doi: 10.1083/jcb.152.5.959

Villar-Cerviño, V., Molano-Mazon, M., Catchpole, T., Valdeolmillos, M., Henkemeyer, M., Martinez, L. M., et al. (2013). Contact repulsion controls the dispersion and final distribution of Cajal-Retzius cells. Neuron 77, 457-471. doi: 10.1016/j.neuron.2012.11.023

Voss, A. K., Britto, J. M., Dixon, M. P., Sheikh, B. N., Collin, C., Tan, S. S., et al. (2008). C3G regulates cortical neuron migration, preplate splitting and radial glial cell attachment. Development 135, 2139-2149. doi: 10.1242/dev. 016725

Wang, Q., Lu, J., Yang, C., Wang, X., Cheng, L., Hu, G., et al. (2002). CASK and its target gene Reelin were co-upregulated in human esophageal carcinoma. Cancer Lett. 179, 71-77. doi: 10.1016/s0304-3835(01)00846-1

Wasser, C. R., Masiulis, I., Durakoglugil, M. S., Lane-Donovan, C., Xian, X., Beffert, U., et al. (2014). Differential splicing and glycosylation of Apoer2 alters synaptic plasticity and fear learning. Sci. Signal. 7:ra113. doi: 10.1126/scisignal. 2005438

Weeber, E. J., Beffert, U., Jones, C., Christian, J. M., Forster, E., Sweatt, J. D., et al. (2002). Reelin and ApoE receptors cooperate to enhance hippocampal synaptic plasticity and learning. J. Biol. Chem. 277, 39944-39952. doi: 10. 1074/jbc.m205147200

Wierenga, C. J., Müllner, F. E., Rinke, I., Keck, T., Stein, V., and Bonhoeffer, T. (2010). Molecular and electrophysiological characterization of GFP-expressing
CA1 interneurons in GAD65-GFP mice. PLoS One 5:e15915. doi: 10. 1371/journal.pone.0015915

Wirths, O., Multhaup, G., Czech, C., Blanchard, V., Tremp, G., Pradier, L., et al. (2001). Reelin in plaques of $\beta 1$-amyloid precursor protein and presenilin1 double-transgenic mice. Neurosci. Lett. 316, 145-148. doi: 10.1016/s03043940(01)02399-0

Xu, M., Arnaud, L., and Cooper, J. A. (2005). Both the phosphoinositide and receptor binding activities of Dab1 are required for Reelin-stimulated Dab1 tyrosine phosphorylation. Brain Res. Mol. Brain Res. 139, 300-305. doi: 10. 1016/j.molbrainres.2005.06.001

Xu, J., Litterst, C., Georgakopoulos, A., Zaganas, I., and Robakis, N. K. (2009). Peptide EphB2/CTF2 generated by the gamma-secretase processing of EphB2 receptor promotes tyrosine phosphorylation and cell surface localization of N-methyl-D-aspartate receptors. J. Biol. Chem. 284, 27220-27228. doi: 10. 1074/jbc.M109.048728

Yang, X. V., Banerjee, Y., Fernandez, J. A., Deguchi, H., Xu, X., Mosnier, L. O., et al. (2009). Activated protein C ligation of ApoER2 (LRP8) causes Dab1dependent signaling in U937 cells. Proc. Natl. Acad. Sci. U S A 106, 274-279. doi: $10.1073 /$ pnas.0807594106

Yano, M., Hayakawa-Yano, Y., Mele, A., and Darnell, R. B. (2010). Nova2 regulates neuronal migration through an RNA switch in disabled-1 signaling. Neuron 66, 848-858. doi: 10.1016/j.neuron.2010.05.007

Yap, C. C., and Winckler, B. (2015). Adapting for endocytosis: roles for endocytic sorting adaptors in directing neural development. Front. Cell. Neurosci. 9:119. doi: 10.3389/fncel.2015.00119

Yasui, N., Kitago, Y., Beppu, A., Kohno, T., Morishita, S., Gomi, H., et al. (2011). Functional importance of covalent homodimer of reelin protein linked via its central region. J. Biol. Chem. 286, 35247-35256. doi: 10.1074/jbc.M111. 242719

Yasui, N., Nogi, T., and Takagi, J. (2010). Structural basis for specific recognition of reelin by its receptors. Structure 18, 320-331. doi: 10.1016/j.str.2010. 01.010

Ye, T., Ip, J. P., Fu, A. K., and Ip, N. Y. (2014). Cdk5-mediated phosphorylation of RapGEF2 controls neuronal migration in the developing cerebral cortex. Nat. Commun. 5:4826. doi: 10.1038/ncomms5826

Yoneshima, H., Nagata, E., Matsumoto, M., Yamada, M., Nakajima, K., Miyata, T., et al. (1997). A novel neurological mutant mouse, yotari, which exhibits reelerlike phenotype but expresses CR-50 antigen/reelin. Neurosci. Res. 29, 217-223. doi: 10.1016/s0168-0102(97)00088-6

Young-Pearse, T. L., Bai, J., Chang, R., Zheng, J. B., Loturco, J. J., and Selkoe, D. J. (2007). A critical function for beta-amyloid precursor protein in neuronal migration revealed by in utero RNA interference. J. Neurosci. 27, 14459-14469. doi: 10.1523/jneurosci.4701-07.2007

Zhang, G., Assadi, A. H., Mcneil, R. S., Beffert, U., Wynshaw-Boris, A., Herz, J., et al. (2007). The Pafahlb complex interacts with the reelin receptor VLDLR. PLoS One 2:e252. doi: 10.1371/journal.pone.0000252

Zhang, G., Assadi, A. H., Roceri, M., Clark, G. D., and D'Arcangelo, G. (2009). Differential interaction of the Pafahlb alpha subunits with the Reelin transducer Dab1. Brain Res. 1267, 1-8. doi: 10.1016/j.brainres.2009. 02.059

Zhang, H., He, Y., Dai, S., Xu, Z., Luo, Y., Wan, T., et al. (2008). AIP1 functions as an endogenous inhibitor of VEGFR2-mediated signaling and inflammatory angiogenesis in mice. J. Clin. Invest. 118, 3904-3916. doi: 10.1172/JCI36168

Conflict of Interest Statement: The authors declare that the research was conducted in the absence of any commercial or financial relationships that could be construed as a potential conflict of interest.

Copyright (C) 2016 Bock and May. This is an open-access article distributed under the terms of the Creative Commons Attribution License (CC BY). The use, distribution and reproduction in other forums is permitted, provided the original author(s) or licensor are credited and that the original publication in this journal is cited, in accordance with accepted academic practice. No use, distribution or reproduction is permitted which does not comply with these terms. 